\title{
Interplay of community dynamics, temperature, and productivity on the hydrogen isotope signatures of lipid biomarkers
}

\author{
S. Nemiah Ladd ${ }^{1,2}$, Nathalie Dubois ${ }^{2,3}$, and Carsten J. Schubert ${ }^{1,4}$ \\ ${ }^{1}$ Department of Surface Waters - Research and Management, Eawag, Swiss Federal Institute of Aquatic Science and \\ Technology, 6047 Kastanienbaum, Switzerland \\ ${ }^{2}$ Department of Earth Sciences, ETH Zürich, 8092 Zürich, Switzerland \\ ${ }^{3}$ Department of Surface Waters - Research and Management, Eawag, Swiss Federal Institute of Aquatic Science and \\ Technology, 8600 Dübendorf, Switzerland \\ ${ }^{4}$ Institute of Biogeochemistry and Pollutant Dynamics, ETH Zürich, 8092 Zürich, Switzerland \\ Correspondence to: S. Nemiah Ladd (nemiah.ladd@eawag.ch)
}

Received: 22 February 2017 - Discussion started: 27 February 2017

Revised: 20 June 2017 - Accepted: 7 August 2017 - Published: 14 September 2017

\begin{abstract}
The hydrogen isotopic composition $\left(\delta^{2} \mathrm{H}\right)$ of lipid biomarkers has diverse applications in the fields of paleoclimatology, biogeochemistry, and microbial community dynamics. Large changes in hydrogen isotope fractionation have been observed among microbes with differing core metabolisms, while environmental factors including temperature and nutrient availability can affect isotope fractionation by photoautotrophs. Much effort has gone into studying these effects under laboratory conditions with single species cultures. Moving beyond controlled environments and quantifying the natural extent of these changes in freshwater lacustrine settings and identifying their causes is essential for robust application of $\delta^{2} \mathrm{H}$ values of common short-chain fatty acids as a proxy of net community metabolism and of phytoplankton-specific biomarkers as a paleohydrologic proxy.
\end{abstract}

This work targets the effect of community dynamics, temperature, and productivity on ${ }^{2} \mathrm{H} /{ }^{1} \mathrm{H}$ fractionation in lipid biomarkers through a comparative time series in two central Swiss lakes: eutrophic Lake Greifen and oligotrophic Lake Lucerne. Particulate organic matter was collected from surface waters at six time points throughout the spring and summer of 2015, and $\delta^{2} \mathrm{H}$ values of short-chain fatty acids, as well as chlorophyll-derived phytol and the diatom biomarker brassicasterol, were measured. We paired these measurements with in situ incubations conducted with $\mathrm{NaH}^{13} \mathrm{CO}_{3}$, which were used to calculate the production rates of individual lipids in lake surface water. As algal productivity in- creased from April to June, net discrimination against ${ }^{2} \mathrm{H}$ in Lake Greifen increased by as much as $148 \%$ for individual fatty acids. During the same time period in Lake Lucerne, net discrimination against ${ }^{2} \mathrm{H}$ increased by as much as $58 \%$ for individual fatty acids. A large portion of this signal is likely due to a greater proportion of heterotrophically derived fatty acids in the winter and early spring, which are displaced by more ${ }^{2} \mathrm{H}$-depleted fatty acids as phytoplankton productivity increases. Smaller increases in ${ }^{2} \mathrm{H}$ discrimination for phytol and brassicasterol suggest that a portion of the signal is due to changes in net photoautotrophic ${ }^{2} \mathrm{H}$ fractionation, which may be caused by increasing temperatures, a shift from maintenance to high growth, or changes in the community assemblage. The fractionation factors for brassicasterol were significantly different between the two lakes, suggesting that its hydrogen isotope composition may be more sensitive to nutrient regime than is the case for fatty acids or phytol.

\section{Introduction}

Compound-specific hydrogen isotope measurements of lipid biomarkers are an emerging tool with diverse applications to microbial community dynamics (Osburn et al., 2011; Heinzelmann et al., 2016), organic matter cycling (Jones et al., 2008; Li et al., 2009), and paleoclimatology (Sachse et al., 2012, and sources therein). The hydrogen isotopic composition of source water exerts a first- 
order control on lipid hydrogen isotopes (expressed as $\left.\delta^{2} \mathrm{H}=\left({ }^{2} \mathrm{H} /{ }^{1} \mathrm{H}_{\text {Sample }}\right) /\left({ }^{2} \mathrm{H} /{ }^{1} \mathrm{H}_{\text {VSMOW }}\right)-1\right)$ (Sessions et al., 1999; Sauer et al., 2001; Sachs, 2014). However, a number of variables can influence the offset between the $\delta^{2} \mathrm{H}$ values between lipids and source water, which is typically expressed by the fractionation factor $\alpha_{\text {lipid-water }}=$ $\left({ }^{2} \mathrm{H} /{ }^{1} \mathrm{H}_{\text {lipid }}\right) /\left({ }^{2} \mathrm{H} /{ }^{1} \mathrm{H}_{\text {water }}\right)$.

For short-chain $(\mathrm{C}<20)$ fatty acids, which can be synthesized by a diverse range of organisms, including photoautotrophs, chemoautotrophs, and heterotrophs, core metabolism typically exerts a large control on $\alpha_{\text {lipid-water, }}$ with variability in $\delta^{2} \mathrm{H}$ values exceeding $500 \%$ o for organisms grown on the same source water (Zhang et al., 2009a; Osburn et al., 2011; Heinzelmann et al., 2015a; Osburn et al., 2016). These metabolic differences have led to the suggestion that $\delta^{2} \mathrm{H}$ values of short-chain fatty acids can be used as an indicator of net community metabolism (Zhang et al., 2009a; Osburn et al., 2011; Heinzelmann et al., 2016; Osburn et al., 2016). This application has previously been assessed in coastal marine settings (Heinzelmann et al., 2016) and hot springs (Osburn et al., 2011), but not in lakes.

The $\delta^{2} \mathrm{H}$ values of lipids produced exclusively by photoautotrophs, such as alkenones and certain sterols, have received particular attention as a proxy for past water isotopes (Sessions et al., 1999; Sauer et al., 2001; Huang et al., 2004; Sachse et al., 2012; Sachs, 2014), which is useful for paleoclimatologists seeking to reconstruct changes in temperature, moisture source, and the balance of precipitation to evaporation, all of which influence the $\delta^{2} \mathrm{H}$ values of water (Craig and Gordon, 1965; Gat, 1996; Henderson and Schuman, 2009; Steinmann et al., 2013). The hydrogen isotopic composition of lipids produced by cyanobacteria and eukaryotic algae is well correlated with those of source water in laboratory and field settings (Sauer et al., 2001; Huang et al., 2004; Englebrecht and Sachs, 2005; Zhang and Sachs, 2007; Sachse et al., 2012) and is stable under near-surface temperatures and pressures for carbon-bound hydrogen (Sessions et al., 2004; Schimmelmann et al., 2006). Hydrogen isotopes of biomarkers from eukaryotic algae have been successfully applied to infer changes in past climate using sediment cores from diverse lakes (Huang et al., 2002; Sachs et al., 2009; Smittenberg et al., 2011; Atwood and Sachs, 2014; Zhang et al., 2014; Nelson and Sachs, 2016; Richey and Sachs, 2016; Randlett et al., 2017) and marine settings (Pahnke et al., 2007; van der Meer et al., 2007, 2008; Leduc et al., 2013; Vasiliev et al., 2013, 2017; Kasper et al., 2014).

However, among photoautotrophs, there is increasing evidence that $\alpha_{\text {lipid-water }}$ is not constant and can change with variables such as salinity, species, light availability, growth rate, and temperature (summarized in Table 1) (Sachs, 2014 and sources therein; Chivall et al., 2014; M'boule et al., 2014; Nelson and Sachs, 2014; Heinzelmann et al., 2015b; Sachs and Kawka, 2015; van der Meer et al., 2015; Wolhowe et al., 2015; Maloney et al., 2016; Sachs et al., 2016, 2017). While the array of secondary isotope effects may appear daunting, these relationships can provide useful information about past environmental changes in their own right, and developing a thorough understanding of them is important for robust interpretations of $\delta^{2} \mathrm{H}_{\text {lipid }}$ values from phytoplankton.

Most previous investigations into variability in $\alpha_{\text {lipid-water }}$ in algal lipid biosynthesis have been done with controlled cultures of eukaryotes in laboratory settings. While similar relationships between salinity and $\alpha_{\text {lipid-water have been }}$ observed for eukaryotic algal and cyanobacterial lipids in both laboratory (Schouten et al., 2006; Chivall et al., 2014; M'boule et al., 2014; Heinzelmann et al., 2015b; Maloney et al., 2016; Sachs et al., 2016) and field calibrations (Sachse and Sachs, 2008; Sachs and Schwab, 2011; Nelson and Sachs, 2014), the temperature and growth rate effects observed in cultures have yet to be assessed in lacustrine settings where photoautotrophic $\delta^{2} \mathrm{H}_{\text {lipid }}$ values are likely to be applied to reconstruct past hydroclimate. In contrast to cultures, lake water contains a diverse and dynamic community of phytoplankton, most of which contribute lipids to the sediment that cannot be attributed to one particular species. The culturing data that exist are limited to a few species, many of which are only found in marine environments.

In order to evaluate the significance of temperature and growth rate effects on the hydrogen isotopic composition of algal lipids produced in lakes, we collected monthly samples of particulate organic matter in two lakes in central Switzerland throughout the spring and summer of 2015. Both lakes experience similar changes in surface water temperature during this time period, but one of them (Lake Greifen) is characterized by high nutrient availability and increasing algal productivity and biomass throughout the spring and early summer. The other lake (Lake Lucerne) is oligotrophic and had relatively low constant rates of algal productivity throughout the study period. We paired measurements of hydrogen isotope fractionation with in situ incubations designed to determine lipid production rates, allowing us to distinguish between the effects of productivity and temperature on hydrogen isotope fractionation.

In addition to measuring $\delta^{2} \mathrm{H}$ values of brassicasterol (24-methyl cholest-5,22-dien-3 $\beta$-ol) and phytol, lipids that are produced exclusively by photoautotrophs, we also analyzed short-chain fatty acids $\left(n \mathrm{C}_{14: 0}, n \mathrm{C}_{16: 0}, n \mathrm{C}_{16: 1}, n \mathrm{C}_{18: 1}\right)$, which, although they are typically the most abundant lipids in algal and cyanobacterial cells, are also synthesized by heterotrophic and chemoautotrophic microbes. The time series of fatty acid $\delta^{2} \mathrm{H}$ values from an oligotrophic and eutrophic lake presented here is the first opportunity to assess how changes in net community metabolism might be recorded by these compounds in lakes. 
Table 1. Summary of expected changes in $\alpha_{\text {lipid-water }}$ in response to different environmental variables, based on laboratory cultures and field studies in marine settings.

\begin{tabular}{|c|c|c|c|}
\hline Variable & $\begin{array}{l}\text { Sign of correlation } \\
\text { with } \alpha_{\text {lipid-water }}\end{array}$ & Magnitude & References \\
\hline Temperature & Negative & $2-4 \%{ }^{\circ} \mathrm{C}^{-1}$ & Zhang et al. (2009b); Wolhowe et al. (2009) \\
\hline Growth rate & Negative & $\sim 30 \%$ division ${ }^{-1}$ day $^{-1}$ & $\begin{array}{l}\text { Schouten et al. (2006); Zhang et al. (2009b); } \\
\text { Sachs and Kawka (2015); Wolhowe et al. (2015) }\end{array}$ \\
\hline Nutrient availability & Negative & $\begin{array}{l}\sim 40 \% \text { difference between nu- } \\
\text { trient limited and nutrient re- } \\
\text { plete cultures }\end{array}$ & Zhang et al. (2009b); Wolhowe et al. (2015) \\
\hline Light availability & Positive & $\begin{array}{l}\text { Below } \sim 250 \mu \mathrm{mol} \\
\text { photons } \mathrm{m}^{-2} \mathrm{~s}^{-1} \\
\sim 0.2 \% \circ \mathrm{mol}^{-1} \\
\text { photons } \mathrm{m}^{-2} \mathrm{~s}^{-1}\end{array}$ & $\begin{array}{l}\text { van der Meer et al. (2015); Wolhowe et al. (2015); } \\
\text { Sachs et al. (2017) }\end{array}$ \\
\hline Salinity & Positive & $\begin{array}{l}0.5-3 \% \text { practical } \\
\text { salinity unit }(\mathrm{PSU})^{-1}\end{array}$ & $\begin{array}{l}\text { Schouten et al. (2006); Sachse and Sachs (2008); } \\
\text { Sachs and Schwab (2011); Chivall et al. (2014); } \\
\text { M'boule et al. (2014); Nelson and Sachs (2014); } \\
\text { Heinzelmann et al. (2015b); Maloney et al. (2016); } \\
\text { Sachs et al. (2016) }\end{array}$ \\
\hline Species assemblage & Variable & $\begin{array}{l}\text { Differences up to } 160 \% \text { ob- } \\
\text { served for } n \mathrm{C}_{16: 0} \text { fatty acid } \\
\text { among species growing under } \\
\text { identical conditions }\end{array}$ & Schouten et al. (2006); Zhang and Sachs (2007) \\
\hline
\end{tabular}

\section{Methods}

\subsection{Site description}

Lake Greifen (Greifensee) is a small perialpine lake, located in the eastern fringes of the Zurich metropolitan area at $47^{\circ} 21^{\prime} \mathrm{N}$ and $8^{\circ} 40^{\prime} \mathrm{E}$ (Fig. 1). The lake has a surface area of $24 \mathrm{~km}^{2}$ and a maximum depth of $32 \mathrm{~m}$. The lake is fed by three small brooks and has one main outlet, the Glatt canal. Lake Greifen experienced severe eutrophication in the mid20th century (Hollander et al., 1992; Keller et al., 2008). Strict government regulations on nutrient inputs were imposed in the 1970s, and the water quality in the lake has since improved, but its deep water remains anoxic and nutrient levels in the upper water column are still elevated. Winter overturn in the lake brings additional nutrients to the surface water, resulting in large phytoplankton blooms in the spring and summer as temperature and light availability increase (McKenzie, 1982). All samples from Lake Greifen were collected from the northern part of the lake, near a permanent platform maintained by Eawag (at $47^{\circ} 21.99^{\prime} \mathrm{N}, 8^{\circ} 39.89^{\prime} \mathrm{E}$ ).

Lake Lucerne (Vierwaldstättersee) is a large perialpine lake, located in central Switzerland at $47^{\circ} 0^{\prime} \mathrm{N}$ and $8^{\circ} 30^{\prime} \mathrm{E}$ (Fig. 1). The lake, which has a total surface area of $116 \mathrm{~km}^{2}$, is formed of seven distinct basins, of which the deepest is $214 \mathrm{~m}$. The lake is fed by four alpine rivers: the Reuss, Muota, Engelberger $\mathrm{Aa}$, and Sarner $\mathrm{Aa}$, and its primary outflow is Reuss river from the northwest tip of the lake. Although Lake Lucerne experienced a mild eutrophication event in the 1970s, it is oligotrophic today (Bürgi et al., 1999; Bührer and Ambühl, 2001; Thevenon et al., 2012). All samples from Lake Lucerne were collected from the center of Kreuztricher basin (near $8^{\circ} 21^{\prime} \mathrm{N}, 47^{\circ} 0^{\prime} \mathrm{E}$ ), with a water depth of $96 \mathrm{~m}$.

\subsection{Sample collection}

Particulate material in each lake was collected at approximately monthly intervals throughout the spring and summer of 2015 (mid-April through early September). Surface water $(\sim 0.5 \mathrm{~m}$ water depth) was filtered onto a pre-combusted $142 \mathrm{~mm}$ diameter GF/F filter $(0.7 \mu \mathrm{m}$ pore size $)$ using a WTSLV Large Volume Pump (McLane, Massachusetts, USA). Pumping began at $7 \mathrm{~L} \mathrm{~min}^{-1}$ and continued until the flow rate decreased to $4 \mathrm{~L} \mathrm{~min}^{-1}$ or until $25 \mathrm{~min}$ had passed. All filters were collected at midday on sunny or mostly sunny days. Filters were wrapped in combusted aluminum foil and stored in a cool box on ice until transport to the laboratory, where they were stored at $-20^{\circ} \mathrm{C}$ until analysis.

Water samples were collected from surface water before and after pumping began. Samples were collected in $4 \mathrm{~mL}$ screw cap vials, sealed with electrical tape, and stored at room temperature prior to analysis. Depth profiles of temperature, conductivity, $\mathrm{pH}$, turbidity, and dissolved oxygen were 


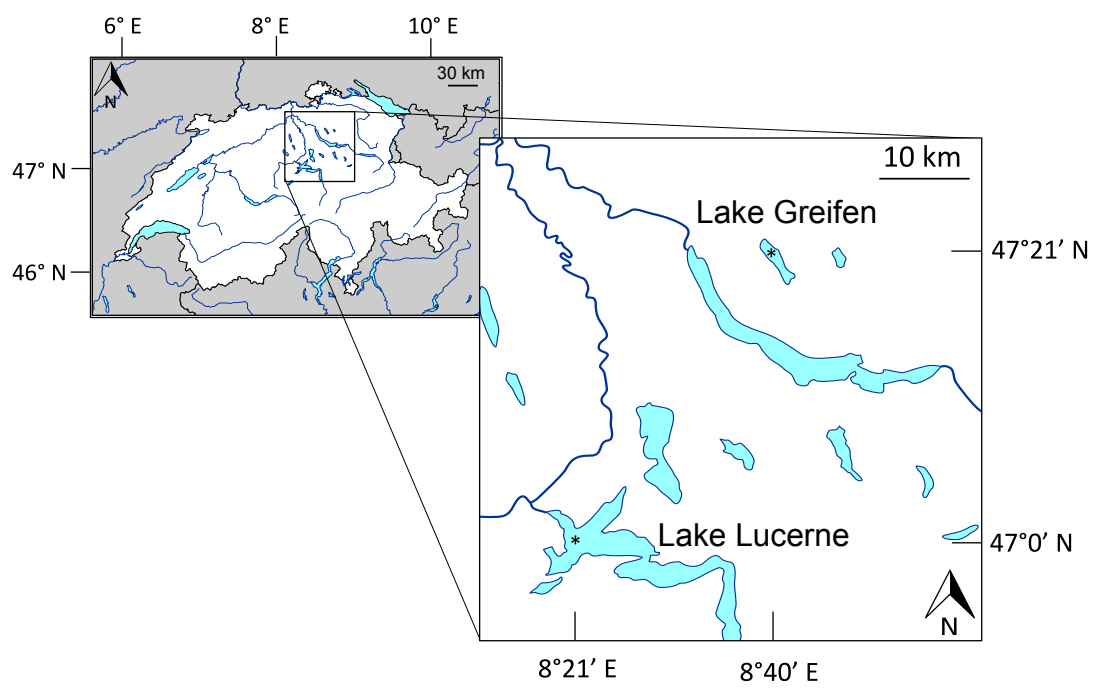

Figure 1. Map of Switzerland with locations of Lake Greifen and Lake Lucerne indicated. Base map from d-maps (http://www.d-maps.com/ carte.php?num_car=2648\&lang=en).

collected for the upper $20 \mathrm{~m}$ of the water column each sampling day at the beginning and end of filtration using a multiparameter CTD probe (75M, Sea and Sun Marine Tech, Trappenkamp, Germany).

On the morning of each sampling day, $4 \times 12.5 \mathrm{~L}$ of surface water was collected in acid-rinsed, autoclaved, transparent carboys for in situ incubations. In two of the four carboys, $1 \mathrm{~mL}$ of concentrated $\mathrm{NaH}^{13} \mathrm{CO}_{3}$ solution was added. The other two carboys were not isotopically labeled. Carboys were mixed and attached to a fixed, floating line so that they stayed in the upper $50 \mathrm{~cm}$ of lake water throughout the day. After $6 \mathrm{~h}$, they were retrieved and the contents were filtered onto a pre-combusted $142 \mathrm{~mm}$ diameter GF/F filter using a peristaltic pump. Water samples for DIC analyses were collected in $12 \mathrm{~mL}$ exetainers prior to isotopic labeling, after labeling but before incubation, and after incubation. These samples were sterile filtered through a $0.2 \mu \mathrm{m}$ syringe filter and stored in the dark at $4{ }^{\circ} \mathrm{C}$ prior to analysis.

\subsection{Water isotope measurements}

Surface water isotope samples were filtered through a $25 \mathrm{~mm}$ syringe filter with a $0.45 \mu \mathrm{m}$ polyethersulfone membrane to remove particulate matter. Water $\delta^{2} \mathrm{H}$ and $\delta^{18} \mathrm{O}$ values were measured by cavity ring-down spectroscopy (CRDS) on a L-2120i water isotope analyzer (Picarro, Santa Clara, CA, USA) at ETH Zurich. Each sample was injected seven times in sequence, and the first four values were discarded to avoid any memory effects from the previous sample. Three water standards with known $\delta^{2} \mathrm{H}$ values of ranging from -161 to $7 \%$ and $\delta^{18} \mathrm{O}$ values ranging from -22.5 to $0.9 \%$ were injected at the beginning and end of each sequence, as well as after every 10 samples. These standards were used to correct measured values to the VSMOW scale and to account for any instrumental drift over the course of the sequence. Average standard deviations (SDs) were $0.4 \%$ for hydrogen isotopes and $0.06 \%$ for oxygen isotopes.

\subsection{DIC concentrations and $\delta^{13} \mathrm{C}$ measurements}

DIC concentrations were measured on a TOC- $\mathrm{L}_{\mathrm{CSH} / \mathrm{CHN}}$ total organic carbon analyzer (Shimadzu, Kyoto, Japan). Solutions with DIC concentrations ranging from 5 to $100 \mathrm{mg} \mathrm{L}^{-1}$ were injected at the beginning of the sequence to form a calibration curve, and one standard of $50 \mathrm{mg} \mathrm{L}^{-1}$ was run after every five samples. Samples were analyzed in triplicate.

Exetainers of $3.7 \mathrm{~mL}$ were prepared for $\delta^{13} \mathrm{C}$ measurements of DIC by adding $100 \mu \mathrm{L}$ of concentrated $\mathrm{H}_{3} \mathrm{PO}_{4}$ and filling the headspace with $\mathrm{He} ; 1 \mathrm{~mL}$ of sample water was added with a syringe through the septa of the exetainer. Samples were allowed to equilibrate overnight before analysis. Carbon isotope values were measured on an isotope ratio mass spectrometer (IRMS) (Isoprime, Stockport, UK). A standard of known isotopic composition was analyzed after every six samples. All samples were measured in duplicate.

\subsection{Lipid extraction and purification}

An internal standard containing $n \mathrm{C}_{19}$-alkanol, $n \mathrm{C}_{19}$-alkanoic acid, and $5 \alpha$-cholestane was quantitatively added to freezedried filters, which were extracted in $30 \mathrm{~mL}$ of 9 : 1 dichloromethane (DCM)/methanol $(\mathrm{MeOH})$ in a SOLVpro microwave reaction system (Anton Paar, Graz, Austria) at $70^{\circ} \mathrm{C}$ for $5 \mathrm{~min}$ (Randlett et al., 2017), centrifuged, and the supernatant containing the total lipid extract (TLE) was poured off and evaporated under a gentle stream of $\mathrm{N}_{2}$. The TLE was saponified with $3 \mathrm{~mL}$ of $1 \mathrm{~N} \mathrm{KOH}$ in $\mathrm{MeOH}$ and 
$2 \mathrm{~mL}$ of solvent-extracted nanopure $\mathrm{H}_{2} \mathrm{O}$ for $3 \mathrm{~h}$ at $80^{\circ} \mathrm{C}$ (Randlett et al., 2017), after which the neutral fraction was extracted with hexane. Subsequently, the aqueous phase was acidified to $\mathrm{pH}=2$, and the protonated fatty acids were extracted with hexane.

Neutral fractions were further purified using silica gel column chromatography, following a scheme modified from Randlett et al. (2017). The sample was dissolved in hexane and loaded onto a $500 \mathrm{mg} / 6 \mathrm{~mL}$ Isolute $\mathrm{Si}$ gel column (Biotage, Uppsala, Sweden). $N$-alkanes were eluted in $4 \mathrm{~mL}$ of hexane, aldehydes and ketones in $4 \mathrm{~mL}$ of 1 : 1 hexane/DCM, alcohols in $4 \mathrm{~mL}$ of 19:1 DCM/MeOH, and remaining polar compounds in $4 \mathrm{~mL}$ of $\mathrm{MeOH}$. The alcohol fraction was acetylated with $25 \mu \mathrm{L}$ of acetic anhydride and $25 \mu \mathrm{L}$ of pyridine for $30 \mathrm{~min}$ at $70^{\circ} \mathrm{C}$. The $\delta^{2} \mathrm{H}$ and $\delta^{13} \mathrm{C}$ values of the added acetyl group were determined by analyzing acetylated and unacetylated $n \mathrm{C}_{10}$-alkanol.

Further purification was necessary in order to obtain base line separation of brassicasterol for $\delta^{2} \mathrm{H}$ measurements. This was achieved by loading the acetylated alcohol fraction onto $500 \mathrm{mg}$ of $\mathrm{Si}$ gel impregnated with $\mathrm{AgNO}_{3}$ (10\% by weight, Sigma Aldrich) in a $6 \mathrm{~mL}$ glass cartridge. The first fraction, containing $n$-alkanols and phytol, was eluted with $20 \mathrm{~mL}$ of $4: 1$ hexane/DCM; the second fraction, containing stanols and singly unsaturated sterols (such as cholesterol) with $20 \mathrm{~mL}$ of $1: 1$ hexane/DCM; the third fraction, containing most doubly unsaturated sterols including brassicasterol, with $16 \mathrm{~mL}$ of DCM; and the remaining compounds with $4 \mathrm{~mL}$ of ethyl acetate.

Fatty acid fractions were methylated with $1 \mathrm{~mL}$ of $\mathrm{BF}_{3}$ in $\mathrm{MeOH}\left(14 \%\right.$ by volume, Sigma Aldrich) for $2 \mathrm{~h}$ at $100^{\circ} \mathrm{C}$. After methylation, $2 \mathrm{~mL}$ of nanopure $\mathrm{H}_{2} \mathrm{O}$ was added to the sample and the fatty acid methyl esters (FAMEs) were extracted with hexane. The $\delta^{2} \mathrm{H}$ and $\delta^{13} \mathrm{C}$ values of the added methyl group were determined by methylating phthalic acid of known isotopic composition (prepared by Arndt Schimmelmann at Indiana University).

FAMEs and brassicasterol were quantified by gas chromatography-flame ionization detection (GC-FID) (Shimazdu, Kyoto, Japan). Samples were injected by an AOC20i autosampler (Shimadzu) through a split/splitless injector operated in splitless mode at $280^{\circ} \mathrm{C}$. The $\mathrm{GC}$ column was an InertCap 5MS/NP $(0.25 \mathrm{~mm} \times 30 \mathrm{~m} \times 0.25 \mu \mathrm{m})(\mathrm{GL}$ Sciences, Japan) and it was heated from 70 to $130^{\circ} \mathrm{C}$ at $20^{\circ} \mathrm{C} \mathrm{min}^{-1}$, then to $320^{\circ} \mathrm{C}$ at $4{ }^{\circ} \mathrm{Cmin}^{-1}$, and held at $320^{\circ} \mathrm{C}$ for $20 \mathrm{~min}$. FAMEs were identified by comparing their retention times to an external standard (fatty acid methyl ester mix from Sulpelco, reference no. 47885-U). Brassicasterol and phtyol were identified by comparing their retention times to those obtained by analyzing a subset of samples by gas chromatography-mass spectrometry (GC-MS) under identical conditions. In order to determine how much of the compound was in the original sample, peak areas were normalized to those of the internal standard. Peak areas were quantified relative to an external calibration curve in order to determine suitable injection volumes for isotopic analysis.

\subsection{Lipid $\delta^{2} \mathrm{H}$ and $\delta^{13} \mathrm{C}$ measurements}

The stable isotope values of individual FAMEs and brassicasterol were measured by gas chromatography-isotope ratio mass spectrometry (GC-IRMS). A GC-1310 gas chromatograph (Thermo Scientific, Bremen, Germany) equipped with an InertCap $5 \mathrm{MS} / \mathrm{NP}(0.25 \mathrm{~mm} \times 30 \mathrm{~m} \times 0.25 \mu \mathrm{m})(\mathrm{GL}$ Sciences, Japan) was interfaced to a Delta Advantage IRMS (Thermo Scientific) with a ConFlow IV interface (Thermo Scientific). Samples were injected with a TriPlusRSH autosampler to a PTV inlet operated in splitless mode at $280^{\circ} \mathrm{C}$. The oven was heated from 80 to $215^{\circ} \mathrm{C}$ at $15^{\circ} \mathrm{Cmin}^{-1}$, then to $320^{\circ} \mathrm{C}$ at $5{ }^{\circ} \mathrm{Cmin}^{-1}$, and then was held at $320^{\circ} \mathrm{C}$ for $10 \mathrm{~min}$. Hydrogen isotope samples were pyrolyzed at $1420^{\circ} \mathrm{C}$ after they eluted from the GC column. Carbon isotope samples were combusted at $1020^{\circ} \mathrm{C}$ after elution.

Raw isotope values were converted to the VSMOW (hydrogen) and VPDB (carbon) scales using Thermo Isodat 3.0 software and pulses of a reference gas that was measured at the beginning and end of each analysis. Sample $\delta^{2} \mathrm{H}$ and $\delta^{13} \mathrm{C}$ values were further corrected using the slope and intercept of measured and known values of isotopic standards $\left(n \mathrm{C}_{17}, 19,21,23,25,28,34\right.$-alkanes; Arndt Schimmelmann, Indiana University), which were run at the beginning and end of each sequence as well as after every six to eight sample injections. Offsets between measured and known values for these standards were used to correct for any drift over the course of the sequence or any isotope effects associated with peak area or retention time. The SD for these standards averaged $4 \%$ and the average offset from their known values was $2 \%$ o for hydrogen isotopes. For carbon isotopes, the average SD of isotopic standards was $0.4 \%$ and the average offset from known values was $0.1 \%$ over the period of analysis.

An additional standard of $n \mathrm{C}_{29}$-alkane was measured three times per sequence, corrected in the same way as the samples, and used for quality control. The SD of these measurements was $4 \%$ for hydrogen and $0.5 \%$ for carbon over the period of analysis. The $\mathrm{H}_{3}^{+}$factor was measured at the beginning of each sequence and averaged $3.6 \pm 0.3$ during the analysis period. Samples were corrected for hydrogen and carbon added during derivatization using isotopic mass balance, and reported errors represent propagated errors from replicate measurements and the uncertainties associated with the added hydrogen.

\subsection{Calculated lipid production rates}

Lipid production rates were calculated using Eq. (1) (modified from Popp et al., 2006):

Production rate $=$

$\left(\delta^{13} \mathrm{C}_{l}-\delta^{13} \mathrm{C}_{n}\right) /\left(\delta^{13} \mathrm{C}_{\mathrm{DIC}}-\delta^{13} \mathrm{C}_{n}\right) \times\left(C_{t} / t\right)$, 
Table 2. Summary of linear regression statistics; bolded relationships are significant at the $p<0.05$ level.

\begin{tabular}{|c|c|c|c|c|c|c|c|c|c|c|}
\hline \multirow[b]{3}{*}{ Lipid } & \multicolumn{5}{|c|}{ Lake Greifen } & \multicolumn{5}{|c|}{ Lake Lucerne } \\
\hline & \multicolumn{10}{|c|}{$\alpha$ lipid water vs. temperature } \\
\hline & Slope & $y$ intercept & $R^{2}$ & $p$ & $n$ & Slope & $y$ intercept & $R^{2}$ & $p$ & $n$ \\
\hline All fatty acids & $-0.006 \pm 0.002$ & $0.95 \pm 0.04$ & 0.32 & 0.004 & 24 & $-0.003 \pm 0.001$ & $0.85 \pm 0.02$ & 0.24 & 0.015 & 24 \\
\hline$n \mathrm{C}_{14: 0}$ fatty acid & $-0.004 \pm 0.001$ & $0.86 \pm 0.03$ & 0.75 & $\mathbf{0 . 0 3}$ & 6 & $-0.0012 \pm 0.0009$ & $0.80 \pm 0.02$ & 0.28 & 0.28 & 6 \\
\hline$n \mathrm{C} 16: 0$ fatty acid & $-0.008 \pm 0.002$ & $0.98 \pm 0.03$ & 0.87 & 0.006 & 6 & $-0.003 \pm 0.001$ & $0.84 \pm 0.02$ & 0.66 & 0.049 & 6 \\
\hline$n \mathrm{C}_{16: 1}$ fatty acid & $-0.005 \pm 0.003$ & $0.98 \pm 0.07$ & 0.35 & 0.22 & 6 & $-0.004 \pm 0.001$ & $0.89 \pm 0.02$ & 0.74 & 0.028 & 6 \\
\hline$n \mathrm{C}_{18: x}$ fatty acid & $-0.006 \pm 0.0003$ & $0.97 \pm 0.007$ & 0.99 & $<0.0001$ & 6 & $-0.004 \pm 0.001$ & $0.89 \pm 0.02$ & 0.70 & $\mathbf{0 . 0 3 7}$ & 6 \\
\hline Phytol & $-0.001 \pm 0.001$ & $0.66 \pm 0.03$ & 0.07 & 0.61 & 6 & $0.002 \pm 0.001$ & $0.62 \pm 0.03$ & 0.47 & 0.20 & 5 \\
\hline \multirow[t]{2}{*}{ Brassicasterol } & $-0.002 \pm 0.001$ & $0.75 \pm 0.02$ & 0.63 & 0.11 & 5 & $0 \pm 0.001$ & $0.76 \pm 0.02$ & 0.00003 & 0.99 & 6 \\
\hline & \multicolumn{10}{|c|}{$\alpha$ lipid water vs. lipid production rate } \\
\hline Lipid & Slope & $y$ intercept & $R^{2}$ & $p$ & $n$ & Slope & $y$ intercept & $R^{2}$ & $p$ & $n$ \\
\hline All fatty acids & $-0.01 \pm 0.01$ & $0.83 \pm 0.02$ & 0.10 & 0.18 & 20 & $-0.04 \pm 0.03$ & $0.81 \pm 0.01$ & 0.09 & 0.19 & 20 \\
\hline$n \mathrm{C}_{14: 0}$ fatty acid & $0.00 \pm 0.02$ & $0.76 \pm 0.02$ & 0.0002 & 0.98 & 5 & $-0.2 \pm 0.2$ & $0.82 \pm 0.05$ & 0.25 & 0.39 & 5 \\
\hline$n \mathrm{C}_{16: 0}$ fatty acid & $0.01 \pm 0.02$ & $0.78 \pm 0.05$ & 0.02 & 0.83 & 5 & $-0.01 \pm 0.04$ & $0.83 \pm 0.03$ & 0.46 & 0.21 & 5 \\
\hline$n \mathrm{C}_{16: 1}$ fatty acid & $-0.17 \pm 0.04$ & $0.89 \pm 0.01$ & 0.84 & 0.03 & 5 & $0.6 \pm 0.6$ & $0.76 \pm 0.06$ & 0.22 & 0.42 & 5 \\
\hline$n \mathrm{C}_{18: \mathrm{x}}$ fatty acid & $-0.01 \pm 0.02$ & $0.85 \pm 0.04$ & 0.08 & 0.64 & 5 & $-0.09 \pm 0.05$ & $0.86 \pm 0.02$ & 0.57 & 0.14 & 5 \\
\hline Phytol & $0 \pm 1$ & $0.63 \pm 0.03$ & 0.03 & 0.77 & 5 & $0 \pm 7$ & $0.66 \pm 0.02$ & 0.001 & 0.95 & 5 \\
\hline Brassicasterol & $2 \pm 2$ & $0.70 \pm 0.01$ & 0.34 & 0.42 & 4 & $5 \pm 43$ & $0.76 \pm 0.03$ & 0.004 & 0.92 & 5 \\
\hline
\end{tabular}

where $\delta^{13} \mathrm{C}_{l}$ is the $\delta^{13} \mathrm{C}$ value of the target compounds from labeled incubations, $\delta^{13} \mathrm{C}_{n}$ is that from unlabeled incubations, $\delta^{13} \mathrm{C}_{\mathrm{DIC}}$ is the $\delta^{13} \mathrm{C}$ value of DIC, $C_{t}$ is the concentration of the lipid at the end of the incubation, and $t$ is the duration of the incubation. Residence times - assuming a steady state, the amount of time needed to replace all molecules of a given lipid - were calculated by dividing $C_{t}$ by the production rate, which reduces to Eq. (2):

Residence time $=$

$t \times\left(\delta^{13} \mathrm{C}_{\mathrm{DIC}}-\delta^{13} \mathrm{C}_{n}\right) /\left(\delta^{13} \mathrm{C}_{l}-\delta^{13} \mathrm{C}_{n}\right)$.

\subsection{Statistics}

PRISM software (Graphpad Software Inc., La Jolla, CA, USA) was used to carry out all statistical analyses. Ordinary least-squares regression was used to determine relationships among fractionation factors, temperature, and lipid production rates. Regression lines are only shown where the slope of the regression was significantly different from 0 at the $p<0.05$ level. The results of all linear regression analyses are presented in Table 2. Differences between the slopes of various regressions were assessed using a two-tailed test of the null hypothesis that both slopes are equal. Differences in the mean values of replicate measurements were determined using an unpaired, two-tailed $t$ test and were considered significantly different for $p<0.05$.

\section{Results}

\subsection{Lipid concentrations and production rates}

Lipid concentrations increased significantly in Lake Greifen from April to July and then declined slightly from July to September, except for phytol and $n \mathrm{C}_{161: 1}$ fatty acid, which had increasing concentrations into the late summer (Fig. 2a). $n \mathrm{C}_{16: 0}$ fatty acid had the highest concentrations, while those of $n \mathrm{C}_{16: 1}$ fatty acid were usually the lowest, except in April-May, when $n \mathrm{C}_{14: 0}$ was the least abundant fatty acid. Brassicasterol concentrations were 1-2 orders of magnitude smaller than those of fatty acids and phytol concentrations were intermediate (Fig. 2a). Lipid concentrations in Lake Lucerne were generally an order of magnitude lower than in Lake Greifen (Fig. 2b). Fatty acid concentrations increased significantly from April to May in Lake Lucerne and were then relatively stable throughout the rest of the time series (Fig. 2b). Again, $n \mathrm{C}_{16: 0}$ fatty acid had the highest concentrations and $n \mathrm{C}_{16: 1}$ was the least abundant fatty acid. Phytol concentrations were typically an order of magnitude lower than those of fatty acids in Lake Lucerne and increased slightly over the course of the time series. Brassicasterol concentrations were an order of magnitude lower still and reached a maximum in June (Fig. 2b).

In both lakes, fatty acid production rates were highest for $n \mathrm{C}_{16: 0}$ (palmitic acid), followed by $n \mathrm{C}_{18: \mathrm{x}}$ (unsaturated $\mathrm{C}_{18}$ fatty acids, primarily $n \mathrm{C}_{18: 1 n 9 c}$, or oleic acid), $n \mathrm{C}_{14: 0}$ (myristic acid), and $n \mathrm{C}_{16: 1}$ (palmitoleic acid) (Fig. 2c and d). Phytol and brassicasterol production rates were 2-3 orders of magnitude lower in both lakes than those of fatty acids (Fig. 2c and d). Lipid production rates were up to three times higher 


\begin{tabular}{|ccc|}
$-\mathrm{nC}_{14: 0}$ fatty acid & $\square \mathrm{nC}_{16: 1}$ fatty acid & $\checkmark \mathrm{nC}_{16: 0}$ fatty acid \\
$\nabla \mathrm{nC}_{18: \mathrm{x}}$ fatty acid & $\sim$ Brassicasterol & $\smile$ Phytol \\
\hline
\end{tabular}

Lake Greifen

(a)

(c)
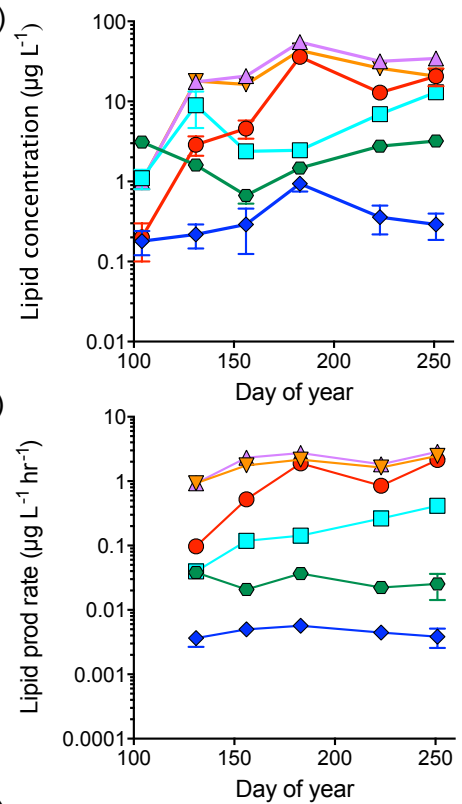

(e)

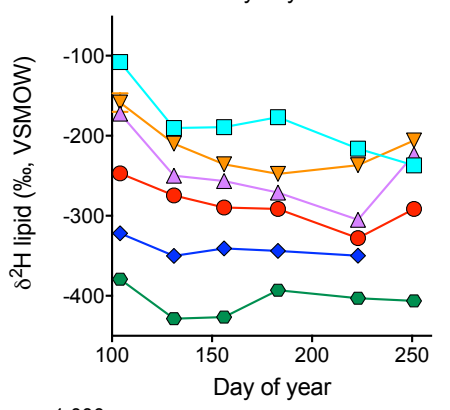

(g)

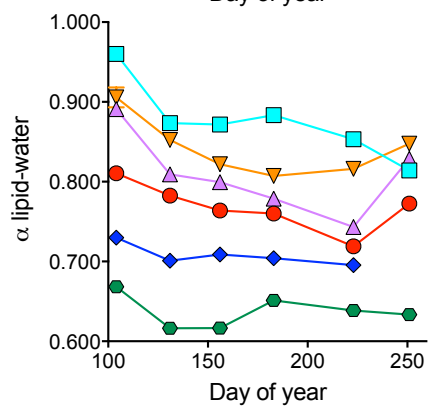

(i)

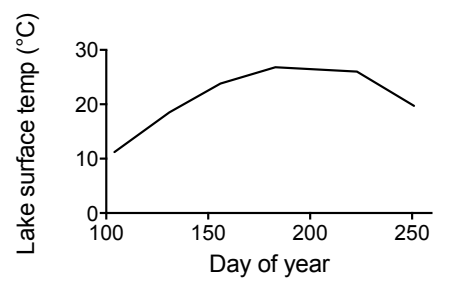

Lake Lucerne

(b)

(d)
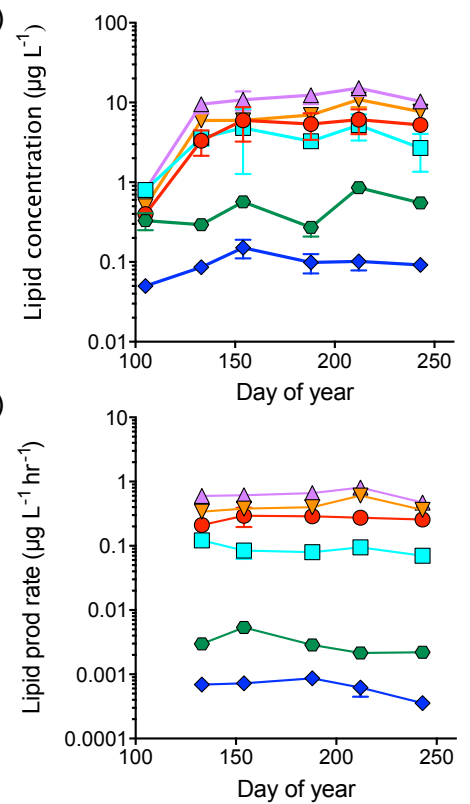

(f)

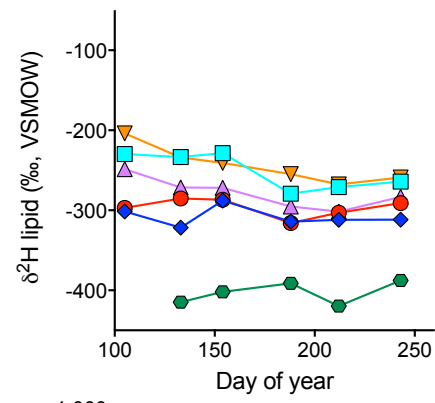

(h)

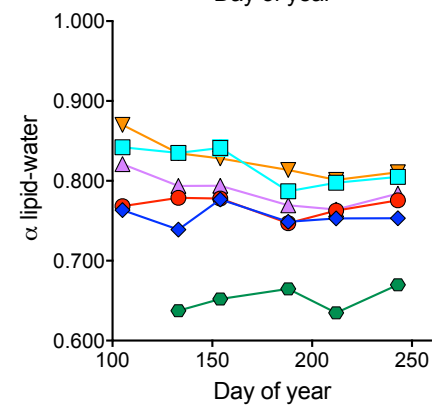

(j)

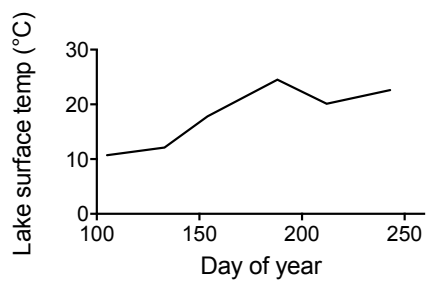

Figure 2. Time series of lipid concentrations in $\mu \mathrm{gL}^{-1}$ (panels a and b), lipid production rates in $\mu \mathrm{gL}^{-1} \mathrm{~h}^{-1}$ (panels $\mathbf{c}$ and $\mathbf{d}$ ), lipid

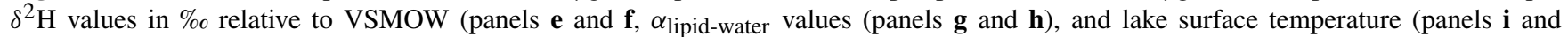
j) for Lake Greifen (left column) and Lake Lucerne (right column) during the spring and summer of 2015. Panels (a-d) are plotted on an exponential scale to accommodate the large range of lipid concentrations and production rates. Error bars represent 1 SD of replicate measurements and are propagated to include uncertainties from multiple sources in calculated production rates and $\alpha_{\text {lipid-water values. In }}$ cases where error bars are not visible, they are smaller than the marker size. 
Table 3. Mean residence times in hours of lipids in lake surface water, calculated according to Eq. (2).

\begin{tabular}{lrrrrrr}
\hline Date & $n \mathrm{C}_{14: 0}$ & $n \mathrm{C}_{16: 0}$ & $n \mathrm{C}_{16: 1}$ & $n \mathrm{C}_{18: \mathrm{x}}$ & Brassicasterol & Phytol \\
\hline Lake Greifen & & & & & & \\
\hline 11 May 2015 & $30 \pm 9$ & $19 \pm 4$ & $60 \pm 13$ & $19 \pm 3$ & $59 \pm 26$ & $42 \pm 10$ \\
5 Jun 2015 & $9 \pm 2$ & $9 \pm 1$ & $21 \pm 2$ & $9 \pm 1$ & $58 \pm 34$ & $32 \pm 8$ \\
2 Jul 2015 & $19 \pm 1$ & $20 \pm 1$ & $49 \pm 5$ & $20 \pm 3$ & $165 \pm 51$ & $40 \pm 6$ \\
11 Aug 2015 & $15 \pm 3$ & $17 \pm 2$ & $41 \pm 5$ & $16 \pm 2$ & $81 \pm 34$ & $123 \pm 23$ \\
8 Sept 2015 & $10 \pm 3$ & $12 \pm 2$ & $31 \pm 8$ & $12 \pm 2$ & $76 \pm 37$ & $127 \pm 26$ \\
\hline Lake Lucerne & & & & & & \\
\hline 13 May 2015 & $16 \pm 6$ & $16 \pm 5$ & $27 \pm 8$ & $17 \pm 2$ & $124 \pm 22$ & $99 \pm 19$ \\
3 Jun 2015 & $20 \pm 12$ & $18 \pm 6$ & $62 \pm 27$ & $16 \pm 4$ & $208 \pm 56$ & $106 \pm 17$ \\
7 Jul 2015 & $19 \pm 8$ & $19 \pm 5$ & $34 \pm 18$ & $17 \pm 5$ & $114 \pm 39$ & $94 \pm 31$ \\
31 Jul 2015 & $22 \pm 9$ & $19 \pm 4$ & $38 \pm 8$ & $18 \pm 4$ & $164 \pm 59$ & $399 \pm 36$ \\
31 Aug 2015 & $20 \pm 4$ & $22 \pm 3$ & $41 \pm 6$ & $12 \pm 3$ & $258 \pm 61$ & $248 \pm 42$ \\
\hline
\end{tabular}

in Lake Greifen than in Lake Lucerne (Fig. 2c and d). Lipid production rates generally increased from May to July and then remained high in Lake Greifen, while in Lake Lucerne they were relatively constant throughout the study period (Fig. 2c and d).

Residence times - or the amount of time necessary to replace all molecules of a given compound assuming steady state - of individual lipids were calculated according to Eq. (2) (Sect. 2.7) and were typically shortest for $n C_{14: 0}$, $n \mathrm{C}_{16: 0}$, and $n \mathrm{C}_{18: \mathrm{x}}$ fatty acids, with values as low as $9 \pm 1 \mathrm{~h}$ in Lake Greifen in May and as low as $12 \pm 3 \mathrm{~h}$ in Lake Lucerne in August (Table 3). Of the fatty acids, $n \mathrm{C}_{16: 1}$ had the longest residence times, reaching $60 \pm 13 \mathrm{~h}$ in Lake Greifen in May and $62 \pm 27 \mathrm{~h}$ in Lake Lucerne in June (Table 3). Brassicasterol residence times were the longest of any lipid in the first part of the time series but were exceeded by phytol for the last two sampling dates (Table 3).

\subsection{Lipid $\delta^{2} \mathbf{H}$ and $\alpha_{\text {lipid-water values }}$}

In both lakes lipid $\delta^{2} \mathrm{H}$ values typically decreased over the spring and summer (Fig. 2e and f). This effect was most pronounced for fatty acids in Lake Greifen. For example, $n \mathrm{C}_{16: 0}$ fatty acid $\delta^{2} \mathrm{H}$ values declined by $133 \%$ o (from -172 to $-305 \%$ ) from April to August in Lake Greifen, while they only declined by $53 \%$ (from -249 to $-302 \%$ ) over the same time period in Lake Lucerne (Fig. 2e and f). During the same time period water $\delta^{2} \mathrm{H}$ values increased slightly in Lake Greifen (from -73 to $-65 \%$ ) and were relatively constant in Lake Lucerne (fluctuating between -82 and $-86 \%$ ) (Supplement Sect. S2). Changes in the fractionation factor between fatty acids and surface water $\left(\alpha_{\text {lipid-water }}\right)$ were therefore linked closely to changes in fatty acid $\delta^{2} \mathrm{H}$ values. In

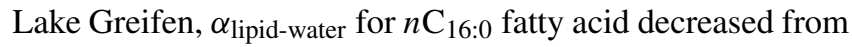
0.891 to 0.743 from April to August (Fig. 2g), while in Lake Lucerne it decreased from 0.821 to 0.763 (Fig. 2h). Similar

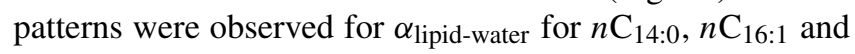

$n \mathrm{C}_{18: \mathrm{X}}$ fatty acids (Fig. $2 \mathrm{~g}$ and $\mathrm{h}$ ). Values for $\alpha_{\text {lipid-water were }}$ less variable for phytol and brassicasterol than for fatty acids, although they also declined from April to May. Brassicasterol was always ${ }^{2} \mathrm{H}$-depleted relative to fatty acids in Lake Greifen and was depleted in ${ }^{2} \mathrm{H}$ relative to all fatty acids except $n \mathrm{C}_{14: 0}$ in Lake Lucerne (Fig. $2 \mathrm{~g}$ and h). Phytol $\delta^{2} \mathrm{H}$ values were the most ${ }^{2} \mathrm{H}$ depleted of any lipid measured in either lake (Fig. 2g and h).

Overall, fatty acid $\alpha_{\text {lipid-water values were negatively cor- }}$ related with lake surface temperature (LST) in both lakes $\left(R^{2}=0.32, p=0.004\right.$ in Lake Greifen; $R^{2}=0.24, p=$ 0.01 in Lake Lucerne) (Fig. 3; Table 2). The slope of the relationship was significantly steeper $(p=0.03)$ in Lake Greifen than in Lake Lucerne $(m=-0.006 \pm 0.002$ in Lake Greifen and $-0.003 \pm 0.001$ in Lake Lucerne). Significant correlations were observed between LST and $\alpha_{\text {lipid-water values for }}$ most fatty acids but not for $n \mathrm{C}_{16: 1}$ in Lake Greifen and $n \mathrm{C}_{14: 0}$ in Lake Lucerne (Fig. 3; Table 2). Significant relationships

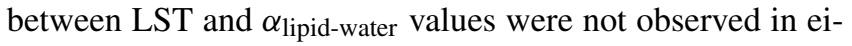
ther lake for brassicasterol or phytol (Fig. 3; Table 2).

Fatty acid production rates were not correlated with $\alpha_{\text {lipid-water values in either lake (Table 2). Among individual }}$ fatty acids, only $n \mathrm{C}_{16: 1}$ fatty acids from Lake Greifen had a significant negative correlation between $\alpha_{\text {lipid-water values }}$ and production rate $\left(R^{2}=0.84 ; p=0.03\right)$ (Table 2). Brassicasterol and phytol production rates were not correlated with $\alpha_{\text {lipid-water }}$ in either lake (Table 2), although brassicasterol $\alpha_{\text {lipid-water values from Lake Lucerne cluster as a signif- }}$ icantly higher group than in Lake Greifen $(p=0.0004)$.

\section{Discussion}

In both lakes, the most striking feature of the lipid $\delta^{2} \mathrm{H}$ values in the particulate organic matter is the significant decrease that occurs for most lipids during the spring (AprilJune) (Fig. 2e and f). As the lake water $\delta^{2} \mathrm{H}$ values increased 


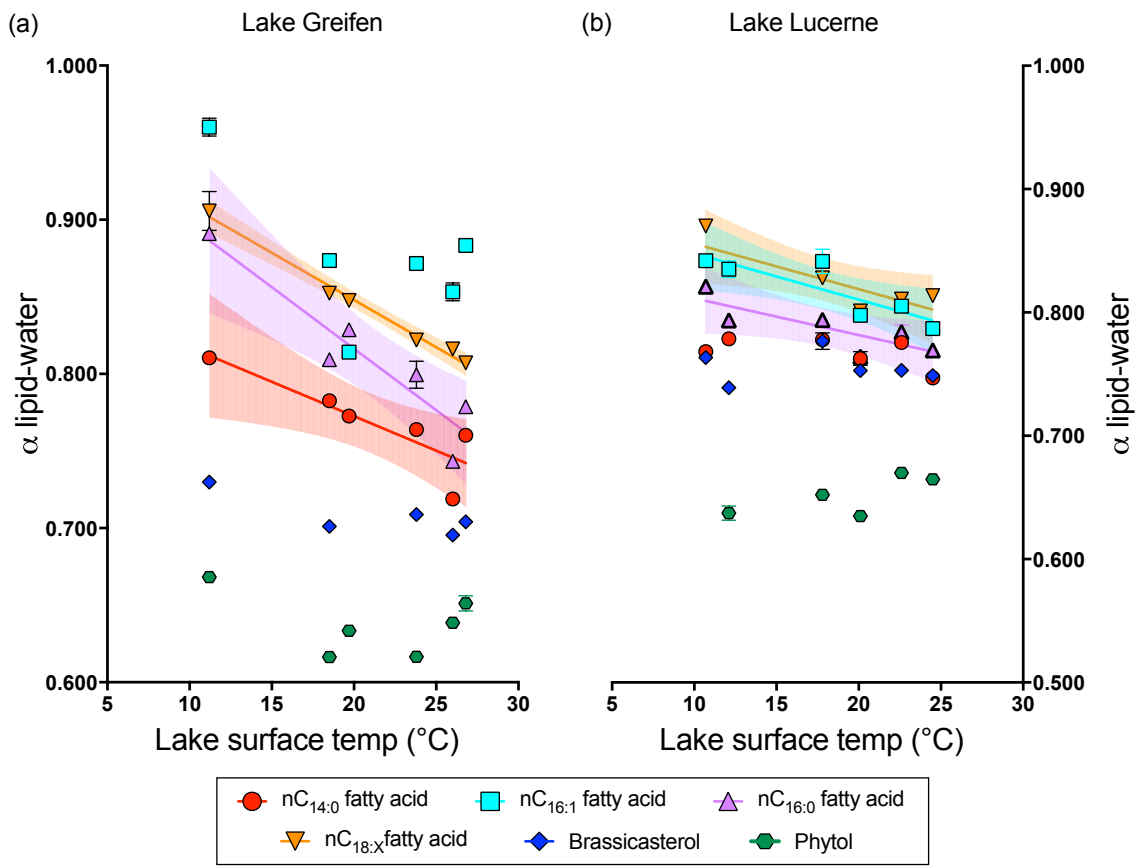

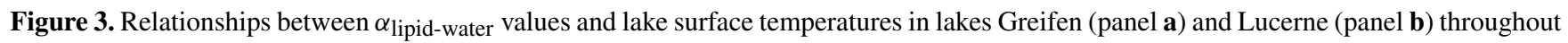
the spring and summer of 2015. Error bars are propagated $1 \sigma$ uncertainty from replicate measurements of surface water and lipid $\delta^{2} \mathrm{H}$ values. In cases where error bars are not visible, they are smaller than the marker size. Shading represents $95 \%$ confidence intervals of the linear regression. Statistics associated with each curve are summarized in Table 2, and plots of individual compounds are available in the Supplement.

slightly (Greifen) or remained constant (Lucerne) throughout the summer, this trend indicates a decrease in $\alpha_{\text {lipid-water }}$ (Fig. $2 \mathrm{~g}$ and h). There are a number of factors that could contribute to this decline in $\alpha_{\text {lipid-water }}$, but they generally group into two categories: changes in lipid source or changes in environmental variables, such as temperature, light, and productivity.

\subsection{Potential changes in lipid source}

Hydrogen isotope fractionation for short-chain fatty acids varies significantly among organisms with different metabolisms (Zhang et al., 2009a; Osburn et al., 2011; Heinzelmann et al., 2015a). In general, fatty acids from heterotrophs grown on tricarboxylic acid (TCA) cycle precursors are most enriched in ${ }^{2} \mathrm{H}$, followed by heterotrophs grown on sugars, then photoautotrophs, and finally chemoautotrophs (Zhang et al., 2009a; Osburn et al., 2011; Heinzelmann et al., 2015a). This variability can be greater than $500 \%$ and has led to the suggestion that the $\delta^{2} \mathrm{H}$ values of ubiquitous compounds such as palmitic acid can be used as a proxy of net community metabolism. For example, at a coastal site in the North Sea, fatty-acid-chain-weighted average $\delta^{2} \mathrm{H}$ values declined by more than $40 \%$ o during the spring phytoplankton bloom, which was attributed to increased contributions from photoautotrophs (Heinzelmann et al., 2016).
In lakes Lucerne and Greifen, large decreases in fatty acid $\delta^{2} \mathrm{H}$ values from April to May coincide with increases in fatty acid concentrations of 1-2 orders of magnitude (Fig. 2). It is therefore possible that the ${ }^{2} \mathrm{H}$-enriched April samples represent a wintertime background of mixed heterotrophic and autotrophic derived compounds. As phytoplankton productivity ramped up with warmer temperatures, water column stratification, and longer daylight hours in the spring, newly produced fatty acids from photoautotrophs could have overwhelmed the heterotrophic signature, causing the net fatty acid $\delta^{2} \mathrm{H}$ values to decrease. The increase in phytoplankton cell density (Fig. 4) from April onward in both lakes is supportive of increased contributions of fatty acids from phytoplankton as the study period progressed.

For Lake Greifen, a simple isotopic mass balance indicates that $31 \%$ of the total $n \mathrm{C}_{16: 0}$ fatty acid would need to come

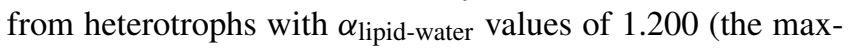
imum observed by Zhang et al., 2009a) in mid-April if the remaining $n \mathrm{C}_{16: 0}$ fatty acid was derived from phytoplank-

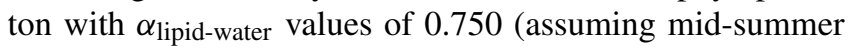
$\alpha_{\text {lipid-water values represent the phytoplankton end member). }}$ Similar calculations suggest that $16 \%$ of $n \mathrm{C}_{16: 0}$ fatty acid would need to come from heterotrophic bacteria in mid-April in Lake Lucerne in order to account for the $50 \%$ o decrease in $n \mathrm{C}_{16: 0}$ fatty acid $\delta^{2} \mathrm{H}$ values over the course of the summer. These calculations assume that all heterotrophic bacteria use 


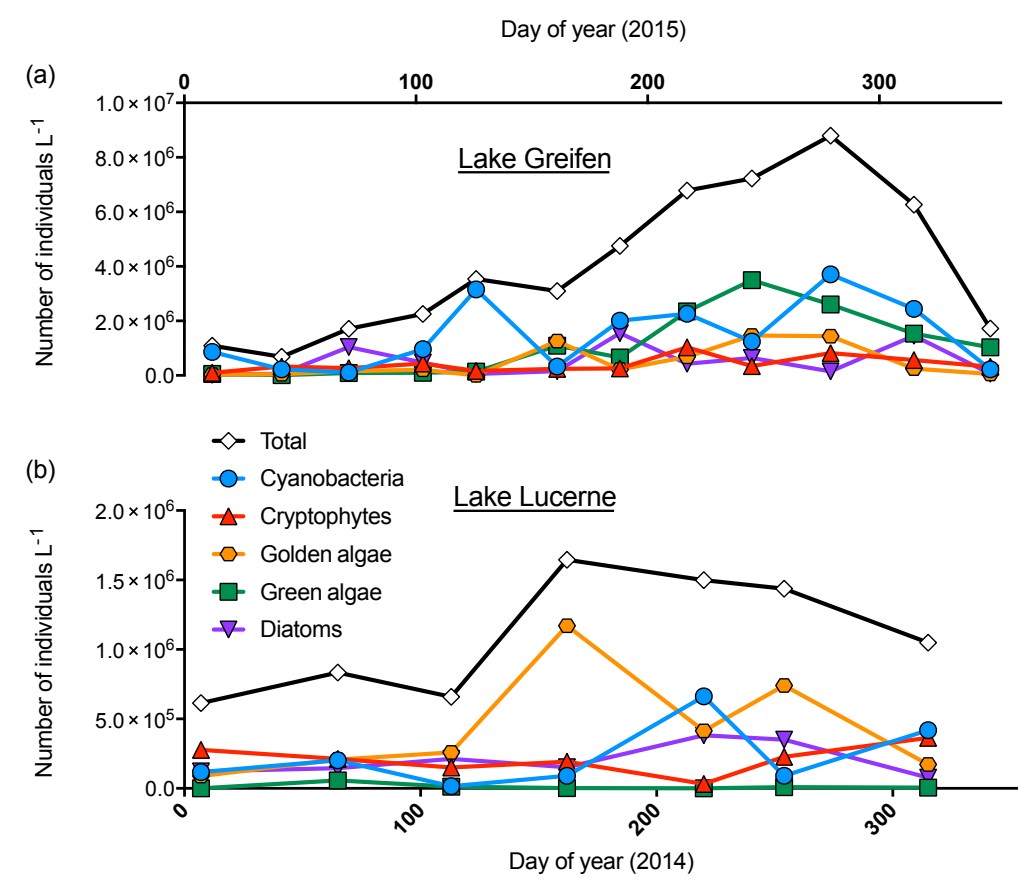

Figure 4. Cell counts (individuals per liter) for all algae and for most common taxa of algae in (a) Lake Greifen throughout 2015 and (b) Lake Lucerne in 2014. The scale of the $y$ axis differs between the two panels. Data from long-term monitoring program are run by the department of Aquatic Ecology at Eawag.

the highest $\alpha_{\text {lipid-water }}$ value ever observed for heterotrophs and that they primarily use the TCA cycle rather than glycolysis. If, as is likely, there is diversity in $\alpha_{\text {lipid-water values for }}$ short-chain fatty acids produced by the heterotrophic bacteria, and at least some of the heterotrophs are relying primarily on glycolysis, the portion of these fatty acids from heterotrophic sources in April would need to be even higher than the values calculated above. This would necessitate a proportionally larger winter heterotrophic contribution of fatty acids than was observed in the coastal North Sea (Heinzelmann et al., 2016), and it seems likely that other variables may contribute to the springtime decline in fatty acid $\delta^{2} \mathrm{H}$ values.

Contributions from heterotrophs are also an improbable explanation for ${ }^{2} \mathrm{H}$-enriched brassicasterol and phytol in April. Brassicasterol is a sterol that is commonly used as a biomarker for diatoms, although it has also been detected in some non-diatom eukaryotic phytoplankton (Volkman et al., 1998; Volkman, 2003; Rampen et al., 2010; Taipale et al., 2016) and occasionally in plant oils (Zarrouk et al., 2009). Since brassicasterol is not produced by bacterial sources, it seems improbable that the $25 \%$ o (Greifen) and $19 \%$ (Lucerne) decreases in its $\delta^{2} \mathrm{H}$ values from April to May could be due to proportionately greater heterotrophic contributions during the winter, as suggested for fatty acids. The 46\% April-May decrease in $\delta^{2} \mathrm{H}$ values of Lake Greifen phytol, the side chain of chlorophyll molecules, is also unlikely to be caused by heterotrophic contributions in the early spring. Although phytol is produced by some photo- heterotrophs, these typically have similar $\alpha_{\text {lipid-water }}$ values to photoautotrophs (Zhang et al., 2009a).

However, seasonal changes in the phytoplankton community composition alone could be a significant source of variability in $\alpha_{\text {lipid-water }}$ over the course of the study period. Hydrogen isotope fractionation for $n \mathrm{C}_{16: 0}$ fatty acid has been demonstrated to vary by over $100 \%$ among five different species of freshwater green algae grown in laboratory batch cultures (Zhang and Sachs, 2007). Such variations may be due to different enzymes involved in lipid synthesis among different species or to the colony-forming behavior of the two species with higher $\alpha_{\text {lipid-water }}$ values. Smaller speciesdependent variations in $\alpha_{\text {lipid-water }}$ have been observed in cultures of haptophytes $(\sim 30 \%$ offset between alkenones in G. oceanica and in E. huxleyi; Schouten et al., 2006). Since there are limited data from culturing experiments, it is not possible to say how widespread such interspecies variability is. It is possible that most phytoplankton display similar magnitudes of hydrogen isotope fractionation during lipid synthesis under similar conditions. However, it is equally possible that lipid hydrogen isotope fractionation varies among species in ways that are not yet understood.

Given this uncertainty, and the significant changes in abundance of different phytoplankton taxa in Lake Greifen over the course of 2015 (Fig. 4a), contributions of lipids from different species of algae with different magnitudes of hydrogen isotope fractionation could account for some or all of the seasonal variability in $\alpha_{\text {lipid-water. A comparable data }}$ 
set of algal species counts does not exist for Lake Lucerne from 2015, but bimonthly data have been compiled from 2014 (Fig. 4b). Some changes in relative distributions of taxa are similar between the two lakes; for example, both Lake Greifen in 2015 and Lake Lucerne in 2014 experienced a peak in golden algae (Chrysophyceae) in June and elevated abundance of cyanobacteria in late summer and late autumn (Fig. 4). Other trends differ starkly between the two lakes. Green algae (Chlorophyceae) are largely absent from Lake Lucerne, while they make up a significant portion of the algal community in Lake Greifen. Notably, the relative abundance of green algae steadily increased from May to September in Lake Greifen (Fig. 4), during which time $\alpha_{\text {lipid-water values }}$ declined at a greater rate for most compounds than they did in Lake Lucerne (Fig. 2). If green algae tend to have lower $\alpha_{\text {lipid-water }}$ values than other algal taxa, their greater abundance in Lake Greifen throughout the summer could account for the greater decline in $\alpha_{\text {lipid-water }}$ over the course of the time series than in Lake Lucerne.

\subsection{Relationships between seasonal environmental gradients and $\alpha_{\text {lipid-water values }}$}

Even for lipids produced in controlled cultures of eukaryotic algae, several factors have been shown to influence hydrogen isotope fractionation, including salinity, light availability, temperature, and growth rate (summarized in Table 1) (Sachs, 2014 and sources therein; Chivall et al., 2014; M'boule et al., 2014; Heinzelmann et al., 2015b; Sachs and Kawka, 2015; van der Meer et al., 2015; Wolhowe et al., 2015; Maloney et al., 2016; Sachs et al., 2016, 2017). Of these, salinity can be excluded as a source of variability freshwater lakes such as Greifen and Lucerne. The effect of light availability on $\alpha_{\text {lipid-water has only been detected at }}$ low light levels (below $250 \mu \mathrm{mol}$ photons $\mathrm{m}^{-2} \mathrm{~s}^{-1}$ ) (van der Meer et al., 2015; Wolhowe et al., 2015; Sachs et al., 2017). Although photosynthetically available radiation (PAR) was not measured as part of the present study, all samples were collected from lake surface water at a midlatitude Northern Hemisphere site during boreal spring and summer, and it is unlikely that PAR was less than $250 \mu \mathrm{mol}$ photons $\mathrm{m}^{-2} \mathrm{~s}^{-1}$ at any sampling date (Pinker and Laszlo, 1992), meaning that the effect of light intensity is unlikely to be a source of the observed seasonal variability in $\alpha_{\text {lipid-water }}$ in lake surface water.

LST varied from 11 to $27^{\circ} \mathrm{C}$ in Lake Greifen and from 11 to $25^{\circ} \mathrm{C}$ in Lake Lucerne over the study period (Fig. $2 \mathrm{i}$ and $\mathrm{j}$ ) and therefore may have contributed to the seasonal changes in lipid $\delta^{2} \mathrm{H}$ values. In laboratory cultures of eukaryotic algae, $\alpha_{\text {lipid-water }}$ values for acetogenic lipids have been shown to decrease by $0.002-0.004^{\circ} \mathrm{C}^{-1}$, resulting in more depleted $\delta^{2} \mathrm{H}$ values (Schouten et al., 2006; Zhang et al., 2009b; Wolhowe et al., 2009, 2015). Increased hydrogen isotope fractionation at higher temperatures has been attributed to (i) changes in the relative activity of different en- zymes involved in lipid synthesis at different temperatures, (ii) changes in the relative amount of NADPH from the pentose phosphate cycle as temperature changes, and (iii) the potential for hydrogen tunneling at higher temperatures as substrate-enzyme complex vibrations increase (Sachs, 2014, and references therein). The relationship between temperature and hydrogen isotope fractionation in cultures is similar to that observed for fatty acids in Lake Lucerne, where

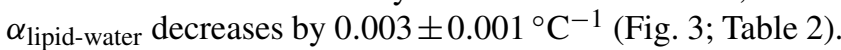
The relationship between $\alpha_{\text {lipid-water }}$ and temperature for fatty acids in Lake Greifen $\left(-0.006 \pm 0.002{ }^{\circ} \mathrm{C}^{-1}\right)$ (Fig. 3; Table 2) is much steeper than that observed in culturing studies.

If the influence of temperature on hydrogen isotope fractionation is consistent among laboratory cultures and lakes, warmer temperatures can account for the entire seasonal change in $\alpha_{\text {lipid-water }}$ for fatty acids in Lake Lucerne. However, increasing temperatures would only be able to explain part of the decrease in fatty acid $\delta^{2} \mathrm{H}$ values in Lake Greifen over the course of the spring and summer. At most, temperature could account for half of the decrease in $\alpha_{\text {lipid-water }}$ in Lake Greifen, assuming a consistent relationship to that observed in cultures.

Brassicasterol and phytol $\alpha_{\text {lipid-water values do not have }}$ strong relationships with LST. There is no correlation between LST and $\alpha_{\text {lipid-water values for phytol in either lake nor }}$ for brassicasterol in Lake Lucerne. In Lake Greifen temperature and $\alpha_{\text {brassicasterol-water }}$ are negatively correlated, although the relationship is not quite significant (Fig. 3f; Table 2). The slope of the relationship between $\alpha_{\text {brassicasterol-water }}$ and LST in Lake Greifen is significantly shallower than that observed for fatty acids $(-0.002 \pm 0.001$ for brassicasterol vs. $0.008- \pm 0.002$ for $n \mathrm{C}_{16: 0}$ fatty acid). Given these relatively weak relationships, it seems unlikely that temperature influences hydrogen isotope fractionation of either brassicasterol or phytol. The negative correlations between temperature and $\alpha_{\text {lipid-water values for fatty acids may therefore be an }}$ artifact of the probable increase in photoautotrophically derived compounds as it became warmer throughout the spring (Sect. 4.1). However, the relationship between temperature and $\alpha_{\text {lipid-water values in cultures has only been observed for }}$ $n$-alkanoic acids and alkenones, both of which are acetogenic lipids. It is thus possible that temperature is partially respon-

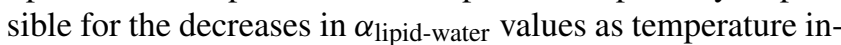
creased in lakes Lucerne and Greifen but that the responsible mechanism is specific to lipids produced acetogenically and does not affect isoprenoids, such as sterols and phytol.

Phytoplankton productivity and biomass also increased with temperature in the spring and summer in lakes Greifen and Lucerne, with a more marked effect in nutrient-rich Greifen (Fig. 2a-d, Fig. 4). This trend could also partially explain the increase in ${ }^{2} \mathrm{H}$ fractionation and decrease in lipid $\delta^{2} \mathrm{H}$ values that co-occurred with rising temperatures. Increased nutrient availability and higher growth rates have been shown to result in lower $\alpha_{\text {lipid-water values during lipid }}$ synthesis for eukaryotic algae in laboratory settings, with 
lipids more ${ }^{2} \mathrm{H}$ depleted relative to source water as growth rate increases (Schouten et al., 2006; Zhang et al., 2009b; Sachs and Kawka, 2015; Wolhowe et al., 2015). This relationship is most likely caused by increased contributions of hydrogen from relatively enriched NADPH from the oxidative pentose phosphate cycle under low-growth, nutrientstressed conditions, at the expense of relatively depleted hydrogen from photosystem I (Schmidt et al., 2003; Sachs and Kawka, 2015). If April samples include a higher proportion of lipids from organisms in a low-growth maintenance phase, they should therefore be relatively enriched in ${ }^{2} \mathrm{H}$. As light availability and water column stratification became more amenable to photosynthesis later in the spring, relatively ${ }^{2} \mathrm{H}$-depleted lipids produced with NADPH from photosystem I would be expected to become more abundant, bringing the net $\delta^{2} \mathrm{H}$ and $\alpha_{\text {lipid-water values down. }}$

Bottle incubations to determine lipid production rates were unfortunately not conducted for the first sampling in April, when the most enriched lipid $\delta^{2} \mathrm{H}$ values were measured. For the remaining five sampling dates, there were not significant correlations between lipid production rate and $\alpha_{\text {lipid-water, }}$, with the exception of $n \mathrm{C}_{16: 1}$ in Lake Greifen (Table 2). Lipid concentrations and production rates are not a direct proxy for growth rate, as a higher percentage of algal biomass is typically allocated to lipids under low nutrient and slow growth conditions (Roessler, 1990; Williams and Laurens, 2010). However, higher lipid production rates for the whole community (rather than on a per cell basis) will co-occur with higher growth rates. The large increase in fatty acid concentrations from April to May in both lakes, as well as smaller increases in brassicasterol concentrations, may indicate that the greatest community-wide change in growth rate occurred between those 2 months and contributes in part to the decrease in fatty acid, phytol, and brassicasterol $\delta^{2} \mathrm{H}$ values from April to May.

\subsection{Comparison of mean $\alpha_{\text {lipid-water in lakes with }}$ different trophic statuses}

For phytol, $n \mathrm{C}_{14: 0}, n \mathrm{C}_{16: 0}$, and $n \mathrm{C}_{18: \mathrm{x}}$ fatty acids, there was no significant difference in $\alpha_{\text {lipid-water }}$ between the oligotrophic and eutrophic lake. However, significant differences in $\alpha_{\text {lipid-water }}$ do exist for brassicasterol $(0.045 \pm 0.008$; $p=0.0004)$ and $n \mathrm{C}_{16: 1}$ fatty acid $(0.058 \pm 0.022 ; p=0.02)$ (Fig. 2). For brassicasterol, $\alpha_{\text {lipid-water }}$ is lower in Lake Greifen $(0.712 \pm 0.006)$ than in the less productive Lake Lucerne $(0.757 \pm 0.005)$. This result would be consistent with decreased hydrogen isotope fractionation (higher $\alpha$ values) for sterols in more nutrient-limited systems, as predicted by culturing experiments (Zhang et al., 2009b; Sachs and Kawka, 2015). The fact that this strong difference in fractionation between the two lakes is observed only for brassicasterol may be because it is the most source specific of the biomarkers that were analyzed. Phytol and short-chain fatty acids are produced by all photoautotrophs and may be dom- inated by phytoplankton that are optimized to grow under the nutrient regimes of each system, while relatively more of the brassicasterol may come from taxa that are nutrientstressed and relying more on the pentose phosphate pathway than photosystem I.

Alternatively, the difference in $\alpha_{\text {brassicasterol-water }}$ values between the two lakes could be due to variable contributions of brassicasterol from different phytoplankton sources. Even though brassicasterol is produced by fewer organisms than short-chain fatty acids and phytol, it still has multiple sources (Volkman et al., 1998; Volkman, 2003; Rampen et al., 2010; Taipale et al., 2016). Species-specific differences in hydrogen isotope fractionation have not been observed for sterols but have been reported for fatty acids and alkenones (Schouten et al., 2006; Zhang and Sachs, 2007), making this an unconstrained possibility that could be responsible for the difference in $\alpha_{\text {brassicasterol-water between the oligotrophic and }}$ eutrophic lake. Different sources could also account for the difference in $\alpha_{\text {lipid-water for }} n \mathrm{C}_{16: 1}$ fatty acid, which displays higher $\alpha_{\text {lipid-water }}$ values in the more productive lake, and therefore cannot be explained by the nutrient effect observed in cultures.

\section{Conclusions}

We measured $\delta^{2} \mathrm{H}$ values of short-chain fatty acids, phytol, and the diatom biomarker brassicasterol in surface water particulate organic matter in two lakes in central Switzerland with different trophic states at six time points throughout the spring and summer of 2015. Measurements were paired with in situ incubations with ${ }^{13} \mathrm{C}$-enriched DIC that allowed us to calculate lipid production rates.

In April in both lakes, lipid concentrations were at their lowest and lipid $\delta^{2} \mathrm{H}$ values were at their highest. In the case of short-chain fatty acids, which are produced by both photoautotrophic and heterotrophic microbes, the relatively high fractionation factors observed in the spring are consistent with a greater proportion of these compounds being derived from heterotrophs (Zhang et al., 2009a; Osburn et al., 2011; Heinzelmann et al., 2015a). As phytoplankton productivity increased throughout the springtime, net $\alpha_{\text {lipid-water }}$ values declined to the range more commonly associated with photoautotrophs. The observed decline in $\alpha_{\text {lipid-water for fatty }}$ acids in oligotrophic Lake Lucerne was similar to that observed during the spring bloom in the North Sea (Heinzelmann et al., 2016) but was nearly three times as large in eutrophic Lake Greifen.

Changing contributions from heterotrophs cannot explain all of the decline in $\alpha_{\text {lipid-water }}$ from April to May, since this was also observed to a lesser extent in phytol and brassicasterol, compounds produced exclusively by photoautotrophs. Several factors could be responsible for changes in photoautotrophic $\alpha_{\text {lipid-water }}$ throughout the spring, including temperature, growth rate, and species assemblage. Fractiona- 
tion factors were inversely correlated with temperature for most fatty acids in each lake, and the slope of this relationship in Lake Lucerne (Fig. 3) was consistent with laboratory cultures, which suggest that $\alpha_{\text {lipid-water }}$ decreases with temperature by $0.002-0.004{ }^{\circ} \mathrm{C}^{-1}$ for acetogenic lipids (Zhang et al., 2009b; Wolhowe et al., 2009). Slower growth rates in the early spring could also result in higher $\alpha_{\text {lipid-water val- }}$ ues at this time, as low growth rates correlate with higher

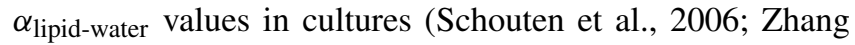
et al., 2009b; Sachs and Kawka, 2015). Finally, changes in phytoplankton species assemblage could have contributed to changes in $\alpha_{\text {lipid-water }}$ over time, as hydrogen isotope fractionation has been observed to vary among eukaryotic algal species grown in culture (Schouten et al., 2006; Zhang and Sachs, 2007; Heinzelmann et al., 2015a)

While average fractionation factors for most lipids were consistent between the two lakes, average $\alpha_{\text {lipid-water values }}$ for brassicasterol were $0.045 \pm 0.008$ lower in Lake Greifen relative to Lake Lucerne, suggesting that sterol hydrogen isotopes may be more sensitive to nutrient availability than those of fatty acids and phytol.

Data availability. The data set associated with this paper is available at https://doi.org/10.3929/ethz-b-000176730 (Ladd et al., 2017).

\section{The Supplement related to this article is available online at https://doi.org/10.5194/bg-14-3979-2017-supplement.}

Author contributions. SNL designed the study with input from ND and CJS. SNL and ND collected the samples. SNL processed and measured the samples. SNL, ND, and CJS contributed to data interpretation. SNL prepared the manuscript with contributions from ND and CJS.

Competing interests. The authors declare that they have no conflict of interest.

Acknowledgements. This research was funded by a National Science Foundation Earth Sciences Postdoctoral Fellowship (award no. 1452254) to NL and Eawag internal funds. Alois Zwyssig and Alfred Lück assisted with sample collection. Serge Robert and Julian Stauffer assisted with sample preparation and laboratory analyses. Daniel Montluçon at ETH Zürich measured the water isotopes. Algal counts were conducted by Esther Keller as part of Eawag's Department of Aquatic Ecology's long-term monitoring program. We had productive conversations with Ashley Maloney, Daniel Nelson, Julian Sachs, Blake Matthews, and Romana Limberger that improved the study design and interpretation of results. Magdalena Osburn and Rienk Smittenberg provided helpful reviews that significantly strengthened the manuscript. We are grateful for all of their contributions.
Edited by: Marcel van der Meer

Reviewed by: Rienk Smittenberg and Magdalena Osburn

\section{References}

Atwood, A. R. and Sachs, J. P.: Separating ITCZ-and ENSOrelated rainfall changes in the Galápagos over the last 3 kyr using $\mathrm{D} / \mathrm{H}$ ratios of multiple lipid biomarkers, Earth Planet. Sc. Lett., 404, 408-419, https://doi.org/10.1016/j.epsl.2014.07.038, 2014.

Bührer, H. and Ambühl, H.: Lake Lucerne, Switzerland, a long term study of 1961-1992, Aquat. Sci., 63, 432-456, https://doi.org/10.1007/s00027-001-8043-8, 2001.

Bürgi, H. R., Heller, C., Gaebel, S., Mookerji, N., and Ward, J. V.: Strength of coupling between phyto-and zooplankton in Lake Lucerne (Switzerland) during phosphorus abatement subsequent to a weak eutrophication, J. Plankton Res., 21, 485-507, https://doi.org/10.1093/plankt/21.3.485, 1999.

Chivall, D., M'Boule, D., Sinke-Schoen, D., Damsté J. S. S., Schouten, S., and van der Meer, M. T. J.: The effects of growth phase and salinity on the hydrogen isotopic composition of alkenones produced by coastal haptophyte algae, Geochim. Cosmochim. Ac., 140, 381-390, https://doi.org/10.1016/j.gca.2014.05.043, 2014.

Craig, H. and Gordon, L.: Deuterium and oxygen 18 variations in the ocean and the marine atmosphere, in: Proceedings of a Conference on Stable Isotopes in Oceanographic Studies and Paleotemperatures, edited by: Tongiori, E., CNR-Laboratorio di Geologia Nucleare, Pisa, Italy, 9-130, 1965.

Englebrecht, A. C. and Sachs, J. P.: Determination of sediment provenance at drift sites using hydrogen isotopes and unsaturation ratios in alkenones, Geochim. Cosmochim. Ac., 69, 42534265, https://doi.org/10.1016/j.gca.2005.04.011, 2005.

Gat, J. R.: Oxygen and hydrogen isotopes in the hydrologic cycle, Annu. Rev. Earth Pl. Sc., 24, 225-262, https://doi.org/10.1146/annurev.earth.24.1.225, 1996.

Heinzelmann, S. M., Villanueva, L., Sinke-Schoen, D., Damsté, J. S. S., Schouten, S., and van der Meer, M. T. J.: Impact of metabolism and growth phase on the hydrogen isotopic composition of microbial fatty acids, Front. Microbiol., 6, 408, https://doi.org/10.3389/fmicb.2015.00408, 2015a.

Heinzelmann, S. M., Chivall, D., M'Boule, D., Sinke-Schoen, D., Villanueva, L., Damsté, J. S. S., Schouten, S., and Van der Meer, M. T. J.: Comparison of the effect of salinity on the $\mathrm{D} / \mathrm{H}$ ratio of fatty acids of heterotrophic and photoautotrophic microorganisms, FEMS Microbiol. Lett., 362, , fnv065, https://doi.org/10.1093/femsle/fnv065, 2015b.

Heinzelmann, S. M., Bale, N. J., Villanueva, L., Sinke-Schoen, D., Philippart, C. J. M., Damsté, J. S. S., Smede, J., Schouten, S., and van der Meer, M. T. J.: Seasonal changes in the D/H ratio of fatty acids of pelagic microorganisms in the coastal North Sea, Biogeosciences, 13, 5527-5539, https://doi.org/10.5194/bg-135527-2016, 2016.

Henderson, A. K. and Shuman, B. N.: Hydrogen and oxygen isotopic compositions of lake water in the western United States, Geol. Soc. Am. Bull., 121, 1179-1189, https://doi.org/10.1130/B26441.1, 2009.

Hollander, D. J., McKenzie, J. A., and Ten Haven, H. L.: A 200 year sedimentary record of progressive eutroph- 
ication in Lake Greifen (Switzerland): implications for the origin of organic-carbon-rich sediments, Geology, 20, 825-828, https://doi.org/10.1130/00917613(1992)020<0825:AYSROP>2.3.CO;2, 1992.

Huang, Y., Shuman, B., Wang, Y., and Webb III, T.: Hydrogen isotope ratios of palmitic acid in lacustrine sediments record late Quaternary climate variations, Geology, 30, 1103-1106, https://doi.org/10.1130/00917613(2002)030<1103:HIROPA>2.0.CO;2, 2002.

Huang, Y., Shuman, B., Wang, Y., and Webb, T.: Hydrogen isotope ratios of individual lipids in lake sediments as novel tracers of climatic and environmental change: a surface sediment test, J. Paleolimnol., 31, 363-375, https://doi.org/10.1023/B:JOPL.0000021855.80535.13, 2004.

Jones, A. A., Sessions, A. L., Campbell, B. J., Li, C., and Valentine, D. L.: D/H ratios of fatty acids from marine particulate organic matter in the California Borderland Basins, Org. Geochem., 39, 485-500, https://doi.org/10.1016/j.orggeochem.2007.11.001, 2008.

Kasper, S., van der Meer, M. T. J., Metz, A., Zahn, R., Damsté J. S. S., and Schouten, S.: Salinity changes in the Agulhas leakage area recorded by stable hydrogen isotopes of C37 alkenones during Termination I and II, Clim. Past., 10, 251-260, https://doi.org/10.5194/cp-10-251-2014, 2014.

Keller, B., Wolinska, J., Manca, M., and Spaak, P.: Spatial, environmental and anthropogenic effects on the taxon composition of hybridizing Daphnia, P. R. Soc. B., 363, 2943-2952, https://doi.org/10.1098/rstb.2008.0044, 2008.

Ladd, S. N., Dubois, N., and Schubert, C. J.: Data set for paper "Interplay of community dynamics, temperature, and productivity on the hydrogen isotope signatures of lipid biomarkers", https://doi.org/10.3929/ethz-b-000176730, 2017.

Leduc, G., Sachs, J. P., Kawka, O. E., and Schneider, R. R.: Holocene changes in eastern equatorial Atlantic salinity as estimated by water isotopologues, Earth Planet. Sc. Lett., 362, 151162, https://doi.org/10.1016/j.eps1.2012.12.003, 2013.

Li, C., Sessions, A. L., Kinnaman, F. S., and Valentine, D. L.: Hydrogen-isotopic variability in lipids from Santa Barbara Basin sediments, Geochim. Cosmochim. Ac., 73, 4803-4823, https://doi.org/10.1016/j.gca.2009.05.056, 2009.

Maloney, A. E., Shinneman, A. L., Hemeon, K., and Sachs, J. P.: Exploring lipid ${ }^{2} \mathrm{H} /{ }^{1} \mathrm{H}$ fractionation mechanisms in response to salinity with continuous cultures of the diatom Thalassiosira pseudonana, Org. Geochem., 101, 154-165, https://doi.org/10.1016/j.orggeochem.2016.08.015, 2016.

M'boule, D., Chivall, D., Sinke-Schoen, D., Sinninghe Damsté, J. S. S., Schouten, S., and van der Meer, M. T. J.: Salinity dependent hydrogen isotope fractionation in alkenones produced by coastal and open ocean haptophyte algae, Geochim. Cosmochim. Ac., 130, 126-135, https://doi.org/10.1016/j.gca.2014.01.029, 2014.

McKenzie, J. A.: Carbon-13 cycle in Lake Greifen: a model for restricted ocean basins, in: Nature and Origin of Cretaceous Carbon-Rich Facies, edited by: Schlanger, S. O., and Cita, M., Academic Press, London, UK, 197-208, 1982.

Nelson, D. B. and Sachs, J. P.: The influence of salinity on D/H fractionation in dinosterol and brassicasterol from globally distributed saline and hypersaline lakes, Geochim. Cosmochim.
Ac., 133, 325-339, https://doi.org/10.1016/j.gca.2014.03.007, 2014.

Nelson, D. B. and Sachs, J. P.: Galápagos hydroclimate of the Common Era from paired microalgal and mangrove biomarker ${ }^{2} \mathrm{H} /{ }^{1} \mathrm{H}$ values, P. Natl. Acad. Sci. USA, 113, 3476-3481, https://doi.org/10.1073/pnas.1516271113, 2016.

Osburn, M. R., Sessions, A. L., Pepe-Ranney, C., and Spear, J. R.: Hydrogen-isotopic variability in fatty acids from Yellowstone National Park hot spring microbial communities, Geochim. Cosmochim. Ac., 75, 4830-4845, https://doi.org/10.1016/j.gca.2011.05.038, 2011.

Osburn, M. R., Dawson, K. S., Fogel, M. L., and Sessions, A. L.: Fractionation of hydrogen isotopes by sulphateand nitrate-reducing bacteria, Front. Microbiol., 7, $1166 \mathrm{~m}$ https://doi.org/10.3389/fmicb.2016.01166, 2016.

Pahnke, K., Sachs, J. P., Keigwin, L., Timmermann, A., and Xie, S.: Eastern tropical Pacific hydrologic changes during the past 27000 years from $\mathrm{D} / \mathrm{H}$ ratios in alkenones, Paleoceanography, 22, PA4214, https://doi.org/10.1029/2007PA001468, 2007.

Pinker, R. T. and Laszlo, I.: Modeling surface solar irradiance for satellite applications on a global scale, J. Appl. Meteorol., 31, 194-211, https://doi.org/10.1175/15200450(1992)031<0194:MSSIFS>2.0.CO;2, 1992.

Popp, B. N., Prahl, F. G., Wallsgrove, R. J., and Tanimoto, J. K.: Seasonal patterns of alkenone production in the subtropical oligotrophic North Pacific, Paleoceanography, 21, PA1004, https://doi.org/10.1029/2005PA001165, 2006.

Rampen, S. W., Abbas, B. A., Schouten, S., and Damsté J. S. S.: A comprehensive study of sterols in marine diatoms (Bacillariophyta): implications for their use as tracers for diatom productivity, Limnol. Oceanogr., 55, 91-105, https://doi.org/10.4319/lo.2010.55.1.0091, 2010.

Randlett, M. E., Bechtel, A., van der Meer, M. T., Peterse, F., Litt, T., Pickarski, N., Kwiecien, O., Stockhecke, M., Wehrli, B., and Schubert, C. J.: Biomarkers in Lake Van sediments reveal dry conditions in eastern Anatolia during 110000-10 000 years BP, Geochem. Geophy. Geosy., 18, 571583, https://doi.org/10.1002/2016GC006621, 2017.

Richey, J. N. and Sachs, J. P.: Precipitation changes in the western tropical Pacific over the past millennium, Geology, 44, 671-674, https://doi.org/10.1130/G37822.1, 2016.

Roessler, P. G.: Environmental control of glycerolipid metabolism in microalgae: commercial implications and future research directions, J. Phycol., 26, 393-399, https://doi.org/10.1111/j.00223646.1990.00393.x, 1990.

Sachs, J. P.: Hydrogen isotope signatures in the lipids of phytoplankton, in: Treatise on Geochemistry, 2nd Edition, edited by: Holland, H. D., and Turekian, K. K., Elsevier, Oxford, UK, 7994, 2014.

Sachs, J. P. and Kawka, O. E.: The influence of growth rate on ${ }^{2} \mathrm{H} /{ }^{1} \mathrm{H}$ fractionation in continuous cultures of the coccolithophorid Emiliania huxleyi and the diatom Thalassiosira pseudonana, Plos one, 10, e0141643, https://doi.org/10.1371/journal.pone.0141643, 2015.

Sachs, J. P. and Schwab, V. F.: Hydrogen isotopes in dinosterol from the Chesapeake Bay estuary, Geochim. Cosmochim. Ac., 75, 444-459, https://doi.org/10.1016/j.gca.2010.10.013, 2011.

Sachs, J. P., Sachse, D., Smittenberg, R. H., Zhang, Z., Battisti, D. S., and Golubic, S.: Southward movement of the Pacific 
intertropical convergence zone AD 1400-1850, Nat. Geosci., 2, 519-525, https://doi.org/10.1038/ngeo554, 2009.

Sachs, J. P., Maloney, A. E., Gregersen, J., and Paschall, C. Effect of salinity on ${ }^{2} \mathrm{H} /{ }^{1} \mathrm{H}$ fractionation in lipids from continuous cultures of the coccolithophorid Emiliania huxleyi, Geochim. Cosmochim. Ac., 189, 96-109, https://doi.org/10.1016/j.gca.2016.05/041, 2016.

Sachs, J. P., Maloney, A. E., and Gregersen, J.: Effect of light on ${ }^{2} \mathrm{H} /{ }^{1} \mathrm{H}$ fractionation in lipids from continuous cultures of the diatom Thalassiosira pseudonana, Geochim. Cosmochim. Ac., 209, 204-215, https://doi.org/10.1016/j.gca.2017.04.008, 2017.

Sachse, D. and Sachs, J. P.: Inverse relationship between D/H fractionation in cyanobacterial lipids and salinity in Christmas Island saline ponds, Geochim. Cosmochim. Ac., 72, 793-806, https://doi.org/10.1016/j.gca.2007.11.022, 2008.

Sachse, D., Billault, I., Bowen, G. J., Chikaraishi, Y., Dawson, T. E., Feakins, S. J., Freeman, K. H., Magill, C. R., McInerney, F. A., van der Meer, M. T. J., Polissar, P., Robins, R. J., Sachs, J. P., Schmidt, H. L., Sessions, A. L., White, J. W. C., West, J. B., and Kahmen, A.: Molecular paleohydrology: interpreting the hydrogen-isotopic composition of lipid biomarkers from photosynthesizing organisms, Annu. Rev. Earth Pl. Sc., 40, 212-249, https://doi.org/10.1146/annurev-earth-042711-105535, 2012.

Sauer, P. E., Eglinton, T. I., Hayes, J. M., Schimmelmann, A., and Sessions, A. L.: Compound-specific D/H ratios of lipid biomarkers from sediments as a proxy for environmental and climatic conditions, Geochim. Cosmochim. Ac., 65, 213-222, https://doi.org/10.1016/S0016-7037(00)00520-2, 2001.

Schimmelmann, A., Sessions, A. L., and Mastalerz, M.: Hydrogen isotopic $(\mathrm{D} / \mathrm{H})$ composition of organic matter during diagenesis and thermal maturation, Annu. Rev. Earth Pl. Sc., 34, 501-533, https://doi.org/10.1146/annurev.earth.34.031405.125011, 2006.

Schmidt, H. L., Werner, R. A., and Eisenreich, W.: Systematics of ${ }^{2} \mathrm{H}$ patterns in natural compounds and its importance for the elucidation of biosynthetic pathways, Phytochem. Rev., 2, 61-85, https://doi.org/10.1023/B:PHYT.0000004185.92648.ae, 2003.

Schouten, S., Ossebaar, J., Schreiber, K., Kienhuis, M. V. M., Langer, G., Benthien, A., and Bijma, J.: The effect of temperature, salinity and growth rate on the stable hydrogen isotopic composition of long chain alkenones produced by Emiliania huxleyi and Gephyrocapsa oceanica, Biogeosciences, 3, 113-119, https://doi.org/10.5194/bg-3-113-2006, 2006.

Sessions, A. L., Burgoyne, T. W., Schimmelmann, A., and Hayes J. M.: Fractionation of hydrogen isotopes in lipid biosynthesis, Org. Geochem., 30, 1193-1200, https://doi.org/10.1016/S01466380(99)00094-7, 1999.

Sessions, A. L., Sylva, S. P., Summons, R. E., and Hayes, J. M.: Isotopic exchange of carbon-bound hydrogen over geologic timescales, Geochim. Cosmochim. Ac., 68, 1545-1559, https://doi.org/10.1016/j.gca.2003.06.004, 2004.

Smittenberg, R. H., Saenger, C., Dawson, M. N., and Sachs, J. P.: Compound-specific D/H ratios of the marine lakes of Palau as proxies for West Pacific Warm Pool hydrologic variability, Quaternary Sci. Rev., 30, 921-933, https://doi.org/10.1016/j.quascirev.2011.01.012, 2011.

Steinman, B. A., Abbott, M. B., Nelson, D. B., Stansell, N. D., Finney, B. P., Bain, D. J., and Rosenmeier, M. F.: Isotopic and hydrologic responses of small, closed lakes to climate variability: comparison of measured and modeled lake level and sedi- ment core oxygen isotope records, Geochim. Cosmochim. Ac., 105, 455-471, https://doi.org/10.1016/j.gca.2012.11.027, 2013.

Taipale, S. J., Hiltunen, M., Vuorio, K., and Petomaa, E.: Suitability of phytosterols alongside fatty acids as chemotaxonomic biomarkers for phytoplankton, Front. Plant Sci., 7, 212, https://doi.org/10.3389/fpls.2016.00212, 2016.

Thevenon, F., Adatte, T., Poté, J., and Spangenberg, J. E.: Recent human-induced trophic change in the large and deep perialpine Lake Lucerne (Switzerland) compared to historical geochemical variations, Palaeogeogr. Palaeocl., 363, 37-47, https://doi.org/10.1016/j.palaeo.2012.08.010, 2012.

van der Meer, M., Baas, M., Rijpstra, W., Marino, G., Rohling, E., Damsté, J. S. S., and Schouten, S.: Hydrogen isotopic compositions of long-chain alkenones record freshwater flooding of the Eastern Mediterranean at the onset of sapropel deposition, Earth Planet. Sc. Lett., 262, 594-600, https://doi.org/10.1016/j.epsl.2007.08.014, 2007.

van der Meer, M., Sangiorgi, F., Baas, M., Brinkhuis, H., Damsté J. S. S., and Schouten, S.: Molecular isotopic and dinoflagellate evidence for Late Holocene freshening of the Black Sea, Earth Planet. Sc. Lett., 267, 426-434, https://doi.org/10.1016/j.epsl.2007.12.001, 2008.

van der Meer, M. T., Benthien, A., French, K. L., Epping, E., Zondervan, I., Reichart, G. J., Bijma, J., Damsté J. S. S., and Schouten, S.: Large effect of irradiance on hydrogen isotope fractionation of alkenones in Emiliania huxleyi, Geochim. Cosmochim. Ac., 160, 16-24, https://doi.org/10.1016/j.gca.2015.03.024, 2015.

Vasiliev, I., Reichart, G. J., and Krijgsman, W.: Impact of the Messinian Salinity Crisis on Black Sea hydrology - insights from hydrogen isotopes analysis on biomarkers, Earth Planet. Sc. Lett., 362, 272-282, https://doi.org/10.1016/j.epsl.2012.11.038, 2013.

Vasiliev, I., Mezger, E. M., Lugli, S., Reichart, G. J., Manzi, V., and Roveri, M.: How dry was the Mediterranean during the Messinian salinity crisis?, Palaeogeogr. Palaeocl., 471, 120-133, https://doi.org/10.1016/j.palaeo.2017.01.032, 2017.

Volkman, J. K.: Sterols in microorganisms, Appl. Microbiol. Biot., 60, 495-506, https://doi.org/10.1007/s00253-002-1172-8, 2003.

Volkman, J. K., Barrett, S. M., Blackburn, S. I., Mansour, M. P., Sikes, E. L., and Gelin, F.: Microalgal biomarkers: a review of recent research developments, Org. Geochem., 29, 1163-1179, https://doi.org/10.1016/S0146-6380(98)00062-X, 1998.

Williams, P. J. L. B. and Laurens, L. M.: Microalgae as biodiesel and biomass feedstocks: review and analysis of the biochemistry, energetics and economics, Energy and Environmental Science, 3, 554-590, https://doi.org/10.1039/B924978H, 2010.

Wolhowe, M. D., Prahl, F. G., Probert, I., and Maldonado, M.: Growth phase dependent hydrogen isotopic fractionation in alkenone-producing haptophytes, Biogeosciences, 8, 16811694, https://doi.org/10.5194/bg-6-1681-2009, 2009.

Wolhowe, M. D., Prahl, F. G., Langer, G., Oviedo, A. M., and Ziveri, P.: Alkenone $\delta \mathrm{D}$ as an ecological indicator: a culture and field study of physiologically-controlled chemical and hydrogenisotopic variation in $\mathrm{C} 37$ alkenones, Geochim. Cosmochim. Ac., 162, 166-182, https://doi.org/10.1016/j.gca.2015.04.034, 2015.

Zarrouk, W., Carrasco-Pancorbo, A., Zarrouk, M., SeguraCarretero, A., and Fernandez-Gutierrez, A.: Multi-component analysis (sterols, tocopherols and triterpenic dialcohols) 
of the unsaponifiable fraction of vegetable oils by liquid chromatography-atmospheric pressure chemical ionization-ion trap mass spectrometry, Talanta, 80, 924-934, https://doi.org/10.1016/j.talanta.2009.08.022, 2009.

Zhang, X., Gillespie, A., and Sessions, A.: Large D/H variations in bacterial lipids reflect central metabolic pathways, P. Natl. Acad. Sci. USA, 106, 12580-12586, https://doi.org/10.1073/pnas.0903030106, 2009a.

Zhang, Z. and Sachs, J. P.: Hydrogen isotope fractionation in freshwater algae: 1. Variations among lipids and species, Org. Geochem., 38, 582-608, https://doi.org/10.1016/j.orggeochem.2006.12.004, 2007.
Zhang, Z., Sachs, J. P., and Marchetti, A.: Hydrogen isotope fractionation in freshwater and marine algae: II. Temperature and nitrogen limited growth rate effects, Org. Geochem., 40, 428-439, https://doi.org/10.1016/j.orggeochem.2008.11.002, 2009b.

Zhang, Z., Leduc, G., and Sachs, J. P.: El Niño evolution during the Holocene revealed by a biomarker rain gauge in the Galápagos Island, Earth Planet. Sc. Lett., 404, 420-434, https://doi.org/10.1016/j.eps1.2014.07.013, 2014. 